\title{
Fazer o bem compensa? Uma reflexão sobre a responsabilidade social empresarial
}

Does doing good bring rewards? An essay on corporate social responsibility Faire du bien est-il compensateur? Une réflexion sur la responsabilité sociale des entreprises

\section{Maria Alice Nunes Costa}

\section{(2penEdition}

\section{Journals}

Edição electrónica

URL: http://journals.openedition.org/rccs/956

DOI: $10.4000 /$ rccs.956

ISSN: 2182-7435

\section{Editora}

Centro de Estudos Sociais da Universidade de Coimbra

Edição impressa

Data de publição: 1 Dezembro 2005

Paginação: 67-89

ISSN: 0254-1106

\section{Refêrencia eletrónica}

Maria Alice Nunes Costa, « Fazer o bem compensa? Uma reflexão sobre a responsabilidade social empresarial », Revista Crítica de Ciências Sociais [Online], 73 | 2005, colocado online no dia 01 outubro 2012, criado a 30 abril 2019. URL : http://journals.openedition.org/rccs/956 ; DOI : 10.4000/rccs.956 


\section{Fazer o bem compensa? Uma reflexão sobre a responsabilidade social empresarial'}

Este artigo apresenta uma visão panorâmica da actual gestão de negócios, denominada de responsabilidade social empresarial, desenvolvida a partir dos anos 1990. Nesse contexto, busca-se compreender as implicações políticas desta forma de solidariedade social, em que agentes económicos intervêm no espaço público, a partir da promoção de políticas de bem-estar social para comunidades de baixa renda. Nesse sentido, a intenção é reflectir sobre a responsabilidade social empresarial, não de maneira isolada, mas a partir de uma expressão que se desenvolve de maneira dinâmica, em interface com o Estado e a comunidade, na governação da regulação social contemporânea.

\section{Apresentação}

Este artigo tem como objetivo apresentar uma reflexão sobre a solidariedade empresarial, discutindo a forma como, a partir dos anos 90 do século passado, alguns empresários vêm se mobilizando para implantar projetos sociais para comunidades de baixa renda.

De acordo com a fórmula clássica, a função do setor privado é realizar sua vocação natural: gerar dividendos para investidores e acionistas, contribuir para o crescimento econômico, criar empregos e fornecer bens e serviços ao mercado. E não há nada de errado nisso, desde que, na consecução de suas atividades, as empresas cumpram com as exigências legais de pagamento de impostos e benefícios trabalhistas, evitem práticas de corrupção e suborno, mantenham auditoria transparente e responsável de seus lucros.

Contudo, além de suas atividades naturais de obtenção de lucro, as empresas têm sido impelidas a fazer mais, a demonstrar que são socialmente responsáveis. Hoje, elas ultrapassam os muros das fábricas e precisam mos-

\footnotetext{
${ }^{1}$ Este artigo se refere aos resultados parciais da pesquisa de doutoramento realizada pela autora, pela Universidade Federal do Rio de Janeiro (IPPUR/UFRJ), sobre o investimento social privado na saúde, no Brasil contemporâneo. A pesquisa incide nas políticas sociais de saúde implementadas através de financiamento de empresas privadas auto-intituladas como socialmente responsáveis. Aqui, o objetivo é apresentar o quadro conceitual e hipóteses de um trabalho empírico em andamento.
} 
trar o seu compromisso com um desenvolvimento baseado em padrões internacionais de sustentabilidade social e ambiental.

Desde os anos 90, vem aumentando o número de empresas que demonstram interesse de expandir sua contribuição social além do que era tradicionalmente habitual. Trata-se de renúncias voluntárias motivadas por uma nova cultura empresarial ou por reconversão de capital para o investimento social privado, em busca de melhoria de imagem e obtenção de capital reputacional.

Algumas empresas brasileiras passaram a criar fundações e institutos, na busca por uma nova natureza que transcenda sua orientação para o lucro, passando a adotar a idéia da responsabilidade social e/ou do investimento social privado (ISP). Esta última forma de contribuição social tem se dado, na maioria dos casos, através de redes sociais para a implantação e desenvolvimento de programas e projetos sociais entre governos, organizações não-governamentais, igrejas, etc. São investimentos feitos em iniciativas sociais para beneficiários externos às empresas. A idéia do ISP refere-se à reconversão de uma percentagem do faturamento bruto da empresa em investimento em iniciativas sociais dirigidas a terceiros. Estas novas formas de contribuição social das empresas têm se dado, de forma geral, em três áreas distintas: a) apoio a programas de governo; b) difusão de melhores práticas (best practices); c) provisão de serviços.

A despeito do seu significado político ou da real mudança social produzida, a solidariedade empresarial tem se mostrado como uma nova fórmula organizacional para a produção do bem comum, em especial na área da assistência social.

O investimento social privado parece ser uma diferente face da capacidade organizativa das empresas, que surge como alternativa à crise do sistema de solidariedade universal compulsória, desenvolvida e financiada pelo Estado. Mesmo que as ações de responsabilidade social empresarial ainda sejam incipientes e realizadas através de iniciativas pontuais, têm-se mostrado determinantes no processo de mobilização da responsabilidade das empresas para com a sociedade, ao lado das ações sociais comunitárias promovidas por organizações não-governamentais.

\section{Uma visão panorâmica da Responsabilidade Social Empresarial}

O envolvimento de empresários com questões sociais não é tão recente quanto pensamos. A diferença atual está na dimensão de escala e no desenvolvimento das práticas sociais desenvolvidas pelos empresários, que tem ultrapassado os limites da empresa e assumido grandes proporções, principalmente a partir dos anos 90. 
Ações coletivas de caridade por parte do Estado e da burguesia já eram utilizadas no século XVIII e XIX (De Swaan, 1992), face à exigência de desativar potenciais antagonismos decorrentes da pobreza, na medida em que a miséria era interpretada em termos de "anti-sociabilidade". Ou seja, a intervenção social empresarial expressava-se através da caridade de empresários beneméritos, como forma de governar a miséria (Beghin, 2003).

No início do século XX, experimentava-se a transição da economia agrícola para a industrial. Com a crescente evolução tecnológica e a aplicação da ciência na organização do trabalho ocorreram mudanças no processo produtivo. A ideologia econômica predominante era o liberalismo e a visão clássica da responsabilidade social empresarial incorporava esses princípios, influenciando a forma de atuação social das empresas e definindo as principais responsabilidades da companhia em relação aos agentes sociais.

Como argumentou Galbraith (1982), nesse período o mercado era formado por empresários em regime de concorrência perfeita. $\mathrm{O}$ patrimônio da companhia se confundia com o patrimônio do dono e a maximização dos lucros era o objetivo maior e expressava a vontade dos acionistas, sendo essa a principal contribuição social da empresa.

Nos Estados Unidos ocorreu um episódio emblemático quanto à responsabilidade social das empresas: o julgamento na justiça americana do caso Dodge versus Ford. Henry Ford, presidente e acionista majoritário, decidiu, em 1916, não distribuir parte dos dividendos esperados, revertendo-os para a realização de objetivos sociais, como aumento de salários e aplicação em um fundo de reserva para a redução esperada de receitas devido ao corte nos preços de carros. Ford agiu contrariando interesses de um grupo de acionistas, como John e Horace Dodge. A Suprema Corte de Michigan se posicionou a favor dos Dodge, justificando que a corporação existe para o benefício de seus acionistas e que diretores corporativos têm livre arbítrio apenas quanto aos meios para se alcançar tal fim, não podendo usar os lucros para outros fins (Ashley et al., 2000).

Desse modo, a prática de ações sociais pelas empresas não era estimulada, sendo até condenada. A responsabilidade social empresarial limitava-se apenas ao ato filantrópico, ${ }^{2}$ isto é, uma ação de natureza assistencialista, caridosa e predominantemente temporária, de caráter pessoal, representada por doações de empresários ou, por exemplo, pela criação de fundações americanas, como a Rockfeller (criada em 1913), a Guggenheim (em 1922) e a Ford (em 1936).

\footnotetext{
${ }^{2}$ A etimologia do termo filantropia significa "amor ao homem ou à humanidade, pressupondo uma ação altruísta e desprendida”, relacionado à caridade, uma virtude cristã.
} 
Com os efeitos da Grande Depressão, a noção de que a corporação deve responder apenas aos acionistas sofreu ataques. No contexto americano, a temática da responsabilidade se impôs às empresas para controlar política e socialmente seu poder, na medida em que, no decorrer dos anos 30, as grandes corporações detinham um enorme poder, até mesmo o poder de interferir nacionalmente na esfera política (Cappellin, 2004: 105).

É nesse contexto que se enquadra o pensamento econômico de J. M. Keynes e sua crítica aos agentes econômicos, expostos em carta de 1936:

[...] Quando a breve recuperação começar, Wall Steet e os banqueiros provavelmente dirão que ela veio por si mesma e teria vindo mais depressa se o governo não houvesse interferido. Eles usarão esse argumento como desculpa para um retorno à completa anarquia. Mas o argumento é falso. A recuperação é, em grande medida, um resultado do que a administração fez, e novas ações governamentais são desejáveis para manter as instrumentalidades que demonstram seu valor. (Keynes, 2002: 20)

Com o keynesianismo e sua política de intervenção do Estado na economia, houve uma redução gradual das incertezas no mercado, o que gerou condições para as empresas investirem em tecnologia, acumularem capital e consolidarem o modelo de produção em massa. Além disso, a transição do modelo de produção resultou em mudanças nos valores da sociedade.

Contudo, foi somente a partir dos anos 40, em parte da Europa, que se registou o apoio empresarial explícito e significativo - parte dos empresários do setor industrial - à necessidade das corporações atuarem com responsabilidade em relação aos seus funcionários e contribuírem de forma efetiva para o bem-estar da sociedade:

Vinte anos mais tarde, em 1942, a idéia aparecia num manifesto subscrito por 120 industriais ingleses, onde afirmavam sem rodeios: 'A responsabilidade dos que dirigem a indústria é manter um equilíbrio justo entre os vários interesses do público como consumidor, dos funcionários e operários como empregados e dos acionistas como investidores. Além disso, dar a maior contribuição possível ao bem-estar da nação como um todo'. (Duarte e Dias, 1986: 187)

Nos EUA, a filantropia empresarial, enraizada pelo legado puritano, possibilitou a conversão de recursos privados em fundos comuns para promover interesses coletivos para atender aos menos favorecidos. Como exemplo, em 1944 foram aplicados 129.900 milhões de dólares em práticas filantrópicas, o que representava, aproximadamente, $2 \%$ do produto nacional bruto 
(Hunter, 1999: 44). Com as pressões da sociedade e do Estado, a ação filantrópica passou a ser promovida pela própria empresa, simbolizando o início da incorporação da temática social na gestão empresarial.

Porém, até a década de 1950, a responsabilidade social empresarial assume dimensão estritamente econômica e é entendida como a capacidade empresarial de geração de lucros, criação de empregos, pagamento de impostos e cumprimento das obrigações legais. Essa era a representação clássica da idéia de responsabilidade social empresarial.

Depois da segunda Guerra Mundial, o entendimento dos empresários em relação aos problemas sociais decorrentes começou a se modificar. Nos EUA, diversas decisões dos tribunais foram favoráveis às ações filantrópicas das corporações. E em 1953 a justiça americana posicionou-se favoravelmente à doação de recursos para a Universidade de Princeton, contrariamente aos interesses de um grupo de acionistas. A justiça determinou, então, que as corporações podiam buscar o desenvolvimento social, estabelecendo em lei a filantropia corporativa (Ashley et al., 2000).

Quanto à nova percepção do empresário em relação à questão social, devemos recordar o próprio pacto social entre os agentes econômicos e o Estado na provisão de bens comuns. O fortalecimento do Estado (o Estado-Providência) fundou-se na aceitação da lógica do lucro pelos trabalhadores e na concorrência dos empresários com as políticas redistributivas, criando condições para o consenso mínimo. No estudo sobre a emergência de políticas nacionais de bem-estar na Europa, De Swaan viu a percepção das elites econômicas sobre os problemas sociais como uma dimensão explicativa central. Na sua perspectiva, somente quando as elites econômicas viram vantagens na coletivização de soluções para os problemas sociais é que o poder público se tornou agente natural na provisão de "bens de cidadania" como educação, saúde e previdência. Ou seja, "tanto para os grandes empresários como para os trabalhadores, a segurança social se converteu cada vez mais numa questão de custos e controles e, finalmente, num tema de negociação" (De Swaan, 1992: 254).

No Brasil, os empresários brasileiros redigiram duas cartas à Nação em 1945 (Carta Econômica de Teresópolis e Carta da Paz Social), divulgadas pela Confederação Nacional da Indústria e do Comércio, em que afirmavam a idéia de harmonia e cooperação entre capital e trabalho, no momento crucial para a definição do papel que deveriam desempenhar as classes produtoras na nova ordem que se anunciava. Além disso, temiam a influência dos comunistas sobre os trabalhadores industriais, em face da insatisfação operária com as condições de trabalho e com os salários recebidos (Delgado, 2001). 
Os empresários brasileiros estavam dispostos a aceitar aumentar suas contribuições para o Estado, com o intuito de ampliar sua ação social. Contudo, esse consenso era relativo. Conforme Barbara Weinstein assinala:

O que os industriais propunham não era um Estado do Bem-Estar Social do tipo que estava sendo criado em países capitalistas mais desenvolvidos, mas antes uma espécie de capitalismo de bem-estar: a atuação direta do capital no fornecimento de produtos mais baratos e serviços sociais para combater a 'pobreza' [...]. (Weinstein, 2000: 162)

Apesar das assimetrias no sistema-mundo, surge algo que pode ser chamado de "consciência social" de todos os membros de uma coletividade nacional vinculados a um substrato de responsabilidade que ia além da ação individual, até alcançar, a partir do reforço das iniciativas de políticos e administradores reformistas encarregados da burocracia estatal, uma orientação para uma política nacional, em que o Estado central proviria à segurança e proteção dos bens coletivos. É a partir desse consenso que se passa a exigir que o Estado se ocupe, com fundos públicos, a dar proteção aos necessitados em geral (De Swaan, 1992: 18-19). Portanto, o Estado-Providência sacrificou capitalistas individuais - que deixaram de ter alguns lucros que tinham antes - em favor, no entanto, de um melhor funcionamento da sociedade. O que, no seu conjunto, acabou por fortalecer o próprio capitalismo.

Com o movimento cultural dos anos 1960, as primeiras gerações do pós-guerra passaram a criticar o modelo de sociedade criada pelo crescimento econômico dos anos 50 e passaram a imaginar a construção de alternativas comunitárias. A idéia era criar uma sociedade fraterna, criativa e comunitária. Nos EUA e parte da Europa, uma parcela da sociedade iniciou uma cobrança efetiva por um comportamento socialmente responsável no âmbito empresarial.

O repúdio à Guerra do Vietname (1964-1973) deu início a um movimento de boicote à aquisição dos produtos e das ações na bolsa de valores daquelas empresas que, de alguma forma, estavam ligadas ao conflito bélico na Ásia. Diversas instituições passaram a exigir uma postura ética e um novo tipo de ação empresarial em relação às questões sociais e ambientais.

A partir de meados dos anos 70, as incertezas passam a dar conta do cenário internacional. A crise do petróleo, aliada a um novo sistema mundial de cunho competitivo, expresso pelo processo de globalização econômica, à retração do Estado e à emergência da sociedade civil na luta pelos direitos humanos e sociais vai impulsionar uma reestruturação no 
mundo empresarial. Nessa crise, o contrato social entre empresários e o Estado é abalado.

A crise econômica e social nos anos 80 passa a ser captada, interpretada e direcionada contra o Estado, gerando um abalo na confiança em relação à sua operacionalidade. Constata-se que a crise fiscal do Estado acabou tendo impacto sobre a sua credibilidade pública, enfraquecendo a percepção de sua finalidade diante da ineficiente administração dos problemas.

Contudo, a crítica ao papel do Estado, corrente nos anos 1980, passou a ser reconceitualizada. Neste período, ocorreu a intensificação dos problemas sociais, com a retomada do liberalismo econômico, o que resultou no surgimento de grande número de organizações não-governamentais movidas pela idéia de solidariedade social. Neste debate, em meados dos anos 1990, surge a proposta de uma nova forma de governação do Estado, em que ele passe a atuar em conjunto com a sociedade civil, o mercado e as empresas na solução dos problemas sociais.

Diversos trabalhos acadêmicos são dirigidos neste sentido. Como afirmou Offe (2000), as antigas opções de desenho institucional que garantam a coesão social estão obsoletas. Para o autor, a provisão da ordem e da estabilidade não podem mais ser baseadas em soluções monísticas, referentes a um dos padrões delimitados pelo Estado, pelo mercado ou pela comunidade. Nesse sentido, o trabalho conjunto dessas três esferas torna-se indispensável, desde que realizado a partir de uma sintonia fina e processual, crítica e flexível entre os três componentes, criando uma fonte de energia para fazer a democracia funcionar.

Refletindo sobre o desempenho das atividades sociais pelas empresas, Alvin Toffler escreve:

Os novos valores pós-econômicos são também evidentes na crescente insistência pública de que as corporações se preocupem também com o desempenho social e não apenas com o econômico, assim como nas tentativas iniciais de criar medidas quantitativas de desempenho social. O movimento dos consumidores e a reivindicação de minorias éticas e subculturais por representação nos conselhos de administração das corporações também estão ligados à idéia de que as corporações não devem mais se empenhar em um único propósito (o econômico), mas sim em se tornarem organizações de 'múltiplos objetivos', ajustando-se ao meio social e ecológico. (Toffler, 1995: 123)

Nesse sentido, na década de 90 passamos a observar o fortalecimento da idéia de responsabilidade social empresarial frente aos desafios da globalização, do acirramento da concorrência internacional, da crise do 
Estado e da mobilização da sociedade. Atento a esse processo, em 1996, o Presidente norte-americano Bill Clinton promoveu uma conferência reunindo empresários, líderes trabalhistas e estudantes para discutir, disseminar e incentivar práticas de empresas socialmente responsáveis (Ashley et al., 2000).

Os movimentos sociais, em especial os ambientalistas, conquistaram uma posição de destaque nesta nova configuração empresarial. Muitas empresas de grande porte, inclusive as responsáveis pela emissão de poluentes, passaram a incluir em sua agenda a questão ecológica. Considera-se uma empresa ambientalmente responsável aquela que age para a manutenção e melhoria das condições ambientais, minimizando ações próprias potencialmente agressivas ao meio ambiente e disseminando em outras empresas as práticas e conhecimentos adquiridos neste sentido.

Nessa trajetória, passa a ser delineado um novo modelo de responsabilidade social empresarial diferenciado da filantropia, na medida em que compartilha projetos comunitários com todas as partes interessadas da empresa (acionistas, clientes, concorrentes, fornecedores e funcionários) e da sociedade (comunidades, governo, etc.). Enquanto a filantropia se limitava à doação de recursos à comunidade e estava relacionada à caridade, limitada por doações efetuadas por empresários ou por fundações criadas por eles, a atual responsabilidade social empresarial promove processos de avaliação e monitorização do investimento social privado na comunidade e na empresa.

A responsabilidade social amplia-se em relação à filantropia na medida em que passa a fazer parte da gestão operacional, com planejamento definido e departamentos específicos dentro da empresa para desenvolver os projetos, implementá-los e controlar os resultados. Nesse sentido, possui indicadores de avaliação para verificar o nível de envolvimento em questões sociais, tais como o Balanço Social ou as certificações de responsabilidade social, para informar a sociedade sobre o seu comportamento socialmente responsável.

Assim, nos anos 90, as empresas passam a desenvolver um laboratório de idéias sobre a responsabilidade social empresarial interna e externa. Contudo, como explicam Cheibub e Locke (2002), não faz sentido denominar de responsabilidade social empresarial o cumprimento da lei:

Da mesma forma, não podemos chamar de responsabilidade social as ações, programas, benefícios, etc. que foram adotados pelas empresas como resultado de negociação trabalhista (acordo, convenção, etc.). Neste caso, estamos diante de uma questão de poder, barganha política, e não de responsabilidade social. (ibid.: 280) 
Ou seja, a responsabilidade social empresarial contém em seu cerne a idéia de ir "além da lei".

Voltada ao público interno de uma empresa, a responsabilidade social empresarial pressupõe um modelo de gestão participativa e de reconhecimento dos empregados, no intuito de motivá-los a um desempenho ótimo que aumente a produtividade corporativa. Envolve, por exemplo, o projeto de qualidade de vida; a busca de condições favoráveis no ambiente de trabalho; o fornecimento de cesta básica de alimentos; a criação de condições de segurança; planos de saúde; plano de cargos e salários; qualificação profissional; etc. Além disso, a responsabilidade social das empresas tem aparecido através de programas de voluntariado, nos quais participam seus empregados, fornecedores e demais parceiros.

Quanto ao foco externo, a responsabilidade social empresarial destina-se a programas e projetos comunitários que a empresa desenvolve por sua iniciativa, ou aquelas desenvolvidas através de parcerias com o governo, com ONGs e com a população organizada de comunidades de baixa renda. Esta modalidade é fortalecida no final dos anos 90 e adquire, também, o sentido de investimento social privado, que para fundações internacionais e agências de cooperação não se refere à operação de projetos próprios ou investimento direto nas comunidades do entorno da empresa. A instituição, no Brasil, que tem trabalhado sobre esta distinção é o Grupo de Institutos, Fundações e Empresas (GIFE), que define o investimento social privado como:

A doação voluntária de fundos privados de maneira planejada e sistemática para projetos sociais de interesse público. [...] Diferentemente de caridade, que vem acompanhada da noção de prover assistência, investidores privados estão preocupados com os resultados obtidos, as mudanças geradas e a participação das comunidades na execução dos projetos. (GIFE, 2001)

Portanto, por mais paradoxal que seja, diante da expansão de seu poderio e complexidade, o mercado passou a ter que enfrentar desafios éticos para as dimensões econômica, ambiental e social dos negócios, necessitando se articular constantemente com governos e com comunidades. Assim, inicia-se a ampliação normativa da responsabilidade social empresarial como uma matriz orientadora estratégica das empresas no mercado altamente competitivo.

A organização não-governamental americana CEPAA (Council on Economic Priorities Accreditation Agency) e a SAI (Social Accountability International), fundadas em 1997 com o propósito de criar códigos de condutas para as empresas, elaboraram em 1998 o padrão Social Accountability 
8000 (SA 8000). A SAI reúne stakeholders estratégicos para desenvolver normas voluntárias baseadas no consenso, acredita organizações qualificadas para verificar o cumprimento de tais normas e promove a compreensão e a implementação das mesmas em escala mundial. Este padrão de sistema de verificação, que consiste nos mesmos critérios da ISO 9000, estabelece estratégias para garantir a qualidade nos negócios, baseando-se em normas dos direitos humanos internacionais, nos acordos de defesa dos Direitos da Criança e do Adolescente, nas resoluções da Organização Internacional do Trabalho (OIT), bem como em toda legislação do país onde se encontra a empresa auditada. ${ }^{3}$ Em Janeiro de 2003, já haviam sido certificadas empresas em 30 países dos cinco continentes, representando 22 setores de atividades.

Algumas empresas têm adotado códigos de ética que abrangem condutas de empregados, relações com a comunidade e o ambiente, fornecedores e prestadores de serviços, atividade política e tecnologia. Essas empresas passaram a ter duas metas dentro de suas estruturas éticas: obter vantagem competitiva e alcançar legitimidade empresarial. A legitimidade empresarial provém de metas, de propósitos e de métodos que sejam consistentes com os da sociedade. Assim, as organizações devem ser sensíveis às expectativas e aos valores da sociedade.

Existem dois grandes códigos de conduta que as empresas internacionais, os governos e os sindicatos tem se comprometido a respaldar: a Declaração Tripartida da OIT e as Diretrizes da OCDE para Empresas Multinacionais. A Declaração Tripartida de princípios da OIT sobre as empresas multinacionais e a política social é composta por 58 cláusulas e foi adotada pelo Conselho de Administração da OIT em novembro de 1977. É um conjunto de recomendações relativas às práticas laborais básicas, fundadas nos princípios da OIT que abarcam questões sociais como emprego, capacitação, condições de trabalho e de vida e relações laborais. Em 2000, o Conselho Ministerial da OCDE adotou consideráveis revisões nas Diretrizes da OCDE para empresas multinacionais, aprovadas inicialmente em 1976. Essas revisões dizem respeito aos princípios e direitos dos trabalhadores enumerados pela Declaração da OIT, além da referência quanto às responsabilidades das empresas multinacionais com relação aos subcontratos e fornecedores e o respeito aos direitos humanos em geral. Especialmente importante foi a decisão de ampliar oficialmente a cobertura das Diretrizes para incluir nelas os operativos mundiais de multinacionais com sede em países que subscreveram esse documento (30 membros da OCDE mais Argentina, Brasil e Chile) (CIOLS, 2001).

\footnotetext{
${ }^{3}$ Ver www.cepaa.org.
} 
No âmbito das Nações Unidas, foi lançado o Pacto Global pelo Secretário Geral, Kofi Annan, no Fórum Mundial Econômico de Davos, em 1999 e em Julho de 2000, em Nova Iorque. É um código de conduta, de adesão voluntária, para empresas e organizações, cujo objetivo é o de formar uma "aliança global" em torno da defesa de direitos e princípios reconhecidos internacionalmente e ratificada pela maioria dos governos. É uma iniciativa internacional, emoldurada no esforço conjunto de empresas, de agências das Nações Unidas e de agentes da sociedade civil e laboral. O código abarca nove princípios em três áreas: direitos humanos, direitos laborais e defesa do ambiente.

No âmbito da União Européia, foi elaborado um documento sobre os caminhos para promover um quadro europeu para a responsabilidade social empresarial, que está contido no Livro Verde da Comissão Européia de 18 de julho de 2001. A definição de responsabilidade social empresarial é definida logo na parte introdutória:

A responsabilidade social das empresas é, essencialmente, um conceito segundo o qual as empresas decidem, numa base voluntária, contribuir para uma sociedade mais justa e para um ambiente mais limpo. [...] Esta responsabilidade manifesta-se em relação aos trabalhadores e, mais genericamente, em relação a todas as partes interessadas afetadas pela empresa e que, por seu turno, podem influenciar os seus resultados. (Comissão das Comunidades Européias, 2001, parágrafo 8)

Realizou-se em Portugal, em 2002, um amplo Seminário Nacional sobre Responsabilidade Social das Empresas, com a presença de empresários, governo e comunidade acadêmica, com o objetivo de refletir sobre uma proposta de responsabilidade social das empresas da seção portuguesa do Centro Europeu das Empresas com Participação Pública e Empresas de Interesse Econômico Geral (CEEP) e do Conselho Econômico e Social da União Européia (CES, 2003). A grande preocupação de Portugal, neste seminário, concentrava-se em entender as diretrizes da União Européia e de que forma poderiam ser adotadas tendo em vista a fraca industrialização de Portugal, associada com o nível social e de cumprimento das normas, aquém dos países europeus mais ricos. Entendeu-se aí que a adoção de responsabilidade social empresarial, apesar das pressões internacionais para a padronização, requer uma interpretação interna das conjunturas econômicas, sociais e políticas do país.

No âmbito da América Latina, muitas organizações empresariais voltadas para a responsabilidade social estão ligadas através de uma rede de relações com a organização empresarial americana BSR (Business Social Responsa- 
bility). Esta rede foi criada a partir de um encontro em Miami, Social Venture Network, em 1997, com o intuito de estabelecer um modelo de responsabilidade social empresarial para ser seguido na América Latina. Temos como exemplo o Instituto Ethos no Brasil, criado em 1998, a Acción Empresarial no Chile (1999), Fundemas em El Salvador (2000). Incluem-se ainda aqui organizações mais antigas, como a Mexican Center for Philanthropy e a Peru 2021, criada em 1994, além de outras organizações similares que estão ativas na Argentina, na Colômbia e Panamá.

Essas organizações têm implementado uma ampla rede com ONGs locais e internacionais, agências governamentais, organizações multilaterais, universidades, centros de pesquisa, fundações filantrópicas americanas, através de uma agenda de conferências nacionais e internacionais sobre práticas de responsabilidade social empresarial na América Latina.

No Brasil, de acordo com informações do Instituto de Pesquisas Econômicas Aplicadas (IPEA, 2001), as 500 maiores empresas do país aplicaram cerca de US $\$ 500$ milhões em projetos sociais no final dos anos 90 . Esta pesquisa realizada pelo IPEA em parceria com o BID (Banco Interamericano de Desenvolvimento) e a Comunidade Solidária de 1998 a 2001, revelou que cerca de 1.400 empresas injetaram um volume de $\mathrm{R} \$ 3,5$ bilhões em atividades sociais na região sudeste do país. O valor correspondeu a 30\% dos investimentos estimados pelo governo para os estados da região Sudeste no mesmo ano, sem incluir os gastos da previdência social, e chegou a 1\% do PIB do Sudeste. No Nordeste o investimento equivale a $4 \%$ e no Sul a 7\% (IPEA, 2001). A mesma pesquisa apontou para o fato de que cresce entre as empresas o entendimento de que uma política de desenvolvimento social exige a participação empresarial em atividades sociais, desde pequenas doações eventuais a pessoas ou instituições até grandes projetos mais estruturados. Essa pesquisa mostra que o setor privado já pode ser considerado o grande interlocutor das políticas públicas do país no tocante às ações sociais.

Das cinco regiões pesquisadas pelo IPEA, a que possuiu mais empresas investindo em projetos sociais é a Sudeste. Nesta região, 67\% disseram realizar algum tipo de ação junto à comunidade, desde atividades eventuais até projetos de âmbito nacional - extensivos ou não aos empregados das empresas e seus familiares. ${ }^{4}$ Em seguida vêm o Nordeste (55\%), Centro-Oeste (50\%), Norte (49\%) e Sul (46\%).

\footnotetext{
${ }^{4}$ Resta ressaltar que o investimento da região Sudeste está atrelado ao seu processo de industrialização. Esta região é o dínamo industrial de todo o país e nela se concentra mais da metade da produção do país, sendo liderada pelo estado de São Paulo. Suas principais concentrações estão associadas às aglomerações metropolitanas de São Paulo, Rio de Janeiro e Belo Horizonte.
} 
Em suma, no quadro atual de mudanças, a idéia de responsabilidade social empresarial surge e se fundamenta em uma nova percepção da gestão dos negócios, atuando como interlocutora perante o Estado e comunidades para a promoção do bem-estar social. De acordo com essa lógica, a gestão das empresas tem estimulado a criação de fundações e institutos empresariais que funcionam como o braço social das empresas, ao contrário das criadas anteriormente, que estavam vinculadas a filantropia pessoal de empresários.

\section{O debate: fazer o bem compensa?}

O tema da Responsabilidade Social Empresarial (RSE) está em moda, tanto no ambiente empresarial quanto no mundo acadêmico e nos media, e, por esta razão, mover-se nele é entrarmos em campo movediço e de batalha, na medida em que ele carrega tensões e, portanto, está longe de ser consensual. Alguns trabalhos mostram uma multiplicidade de definições e práticas empresariais que, muitas vezes, são contraditórias, incongruentes e divergentes. Além de não haver homogeneidade no pensamento empresarial sobre o que seja RSE, este movimento, dirigido pelas empresas, está impregnado de retóricas, discursos e ideologias. E, por estar em pleno curso e em ebulição, dificulta-nos a nos empreendermos por um caminho que ultrapasse essa dimensão.

Desta maneira, a maioria dos trabalhos passa a interpretar o atual movimento da RSE por dois pólos opostos: aqueles que reproduzem e defendem as suas iniciativas, em seu papel de redenção de empresa-cidadã; e outros, que apontam esses esforços como um simples simulacro da idéia de benevolência, por distrair a atenção dos genuínos problemas da ética nos negócios e dos problemas sociais que acarretam as populações mais pobres. Visto isso, não pretendemos afirmar que uma ou outra apenas esteja correta. Ambas são pertinentes em contexto de ampla complexidade frente aos inúmeros problemas sociais. Contudo, é por entender que não há homogeneidade na idéia de responsabilidade social empresarial, que precisamos compreendê-la dentro do contexto da atual das relações sociais e de governação entre o Estado, as empresas e a comunidade em interface com o contexto das mudanças econômicas, políticas e sociais que emergem.

Sendo assim, mais do que julgar, nosso objetivo é o de refletir que as práticas de responsabilidade social empresarial e, em particular, de investimento social privado, envolvem uma nova forma de coesão social expressa em situação específica. Isso requer um processo de tradução das experiências possíveis e disponíveis, que incluem realidades que ultrapassam a dicoto$\mathrm{mia}$ do bom/mau e nas quais se confrontam e dialogam diferentes processos, 
práticas e experiências em movimento. Nelas encontramos racionalidades híbridas, que contêm a idéia de reciprocidade e solidariedade e até mesmo da maximização dos interesses egoístas.

Não tem sido tarefa fácil para as empresas categorizar ou quantificar os benefícios quando adotam ações de responsabilidade social. No entanto, as gestões se debatem sobre quais seriam os resultados organizacionais se tais ações não fossem desencadeadas. Neste cálculo está em jogo sua contribuição para manter o equilíbrio social, minimizando os conflitos sociais, e sua reputação política perante o Estado e a sociedade.

Prevenir os riscos de poluição, de reputação ou sociais pode tornar-se mais rentável que o dever de pagar pelas suas conseqüências; contudo, isto é avaliado pelas empresas dentro do cenário da complexidade política e tecnológica. Esses fatores podem ser uma alavanca para a adoção da política de gestão em responsabilidade social empresarial.

A maioria dos empresários que trabalha com a gestão da responsabilidade social empresarial afirma que ela deve ser trabalhada no domínio da estratégia da empresas. Não deve ser confundida com a caridade, mas sim entendida como algo fundamental à consolidação da empresa. Há que considerar a possibilidade de perda de ganho social em relação à prática de empresários perdulários e imprudentes que geram desperdícios, desemprego ou poluição ambiental.

Porter e Kramer (2002) acreditam que a utilização da responsabilidade social das empresas permite o alinhamento dos objetivos sociais e econômicos e incrementa o potencial de desenvolvimento da empresa a longo prazo. Além disso, atuando sobre o contexto, a empresa obtém mais rendimento, mas também alavanca as suas capacidades e os seus relacionamentos no apoio a causas sociais. Como afirmam os autores:

Não há nenhuma contradição entre melhorar o contexto competitivo e denotar um sério empenho no melhoramento da sociedade. De fato [...], quanto mais a filantropia empresarial se direciona para seu contexto competitivo, mais volumoso é o contributo da empresa para a sociedade. (ibid.: 68)

Do outro lado, há aqueles que devotam à responsabilidade social empresarial veemente oposição, tanto no sentido econômico, como no sentido político mais amplo. No sentido econômico, a referência obrigatória é Milton Friedman, que afirmou em Capitalismo e Liberdade (1985) que a essência da própria responsabilidade social das empresas consiste fundamentalmente na maximização de seus objetivos produtivos, dentro dos ditames da lei. Caso as empresas pretendam ir além, elas estarão sendo irresponsáveis, pois desperdiçarão recursos sociais produtivos. 
No campo do debate econômico mais recente, contrário à responsabilidade social empresarial, destaca-se David Henderson (2001), que já foi o principal economista da OCDE. Com seu livro Misguided Virtue: False Notions of Corporate Social Responsability colocou uma crítica severa em relação à responsabilidade social empresarial, argumentando que, embora os "doutrinadores" da RSE pretendam que ela confira ao capitalismo uma "face humana" e proporcione às empresas o seu desenvolvimento sustentável, os efeitos podem ser contraproducentes. A tese de Herderson contesta mesmo os trabalhos e os princípios propalados por diversas instituições que fomentam a idéia da RSE.

Para Henderson, a RSE assenta numa perspectiva errada e a sua adoção generalizada reduzirá a prosperidade e prejudicará a economia de mercado (ibid:: 18). Sua preocupação está em que o mercado dos países pobres assuma custos adicionais exigidos por padrões internacionais, o que acabará limitando, ainda mais, sua concorrência e piorando o desempenho global da economia como um todo. O autor defende que as atividades empresariais não estão dispensadas do exercício de juízos morais. Contudo, é incumbência do Estado e dos governos, e não das empresas e dos gestores, decidir o que é do interesse público e quais as medidas a tomar para que a busca, pelas empresas, da maximização do lucro contribua para servi-lo.

No âmbito do debate sobre os riscos políticos da intervenção social das empresas no espaço público, Cheibub e Locke (2002), ao analisar diferentes modelos de responsabilidade social empresarial, afirmam que o principal problema é que seus argumentos assumem que todos os outros atores sociais ganham com a adoção de responsabilidade social. Desta maneira, não há a consideração da dimensão política na promoção do bem público. Assim, os autores questionam a maneira pela qual as empresas estariam sendo mais responsáveis: provendo diretamente bem-estar ou fortalecendo o Estado para que ele garanta a universalidade dessa provisão?

Os autores acreditam que há um risco político dessas ações sociais estarem sendo promovidas pelo setor privado, pois podem distorcer o conceito de direitos universais derivados da cidadania, por privilegiar certas necessidades em detrimento de outras e pelo aumento do poder das empresas no controle dos bens coletivos. Ou seja, as ações sociais empresariais podem ser do real interesse maximizador das empresas e dos empresários, mas podem também solapar o bem público.

Em outro trabalho, Paoli (2003), ao avaliar as ações sociais empresariais como uma possibilidade de conter em seu cerne um potencial contra-hegemônico ao modelo neoliberal, conclui que, na verdade, por mais inovador, 
competente e envolvido do apelo de ativismo social por uma nova forma de solidariedade, esse fenômeno mostra a face mais conservadora da solidariedade privada: retira da arena política e pública os conflitos distributivos e a demanda coletiva por cidadania e igualdade.

Para a autora, o centro da reflexão em torno da ação empresarial é a disputa por uma "nova forma de regulação social que aceite, ou recuse, legitimar-se por via da deliberação ampliada sobre a interdependência dos bens públicos e privados" (ibid: 380 ). Ela afirma que essas ações sociais adaptam-se com vantagens às formas do lucro empresarial, preconizando a iniciativa individual e privada contra a ineficiência burocrática do Estado e a politização dos conflitos sociais. Desta forma, as empresas afirmam sua disponibilidade civil em contribuir, no âmbito privado e mercantil, para a redefinição do modo de operar as políticas públicas que se dirigem à integração social e profissional de parcelas da população.

Tais ações domesticam o alcance político próprio da noção de bens públicos à eficiência dos procedimentos privados de gestão, intervindo de modo pulverizado ao abrigo das preferências privadas de financiamento. As ações filantrópicas empresariais rompem com a medida pública ampliada entre necessidades e direitos e, portanto, não criam seu outro pólo: o cidadão participativo que vá além de um beneficiário passivo.

Enfim, diversos autores apontam que as ações de responsabilidade social empresarial nada mais são do que um artifício para usar a questão social como campanha publicitária para encobrir as causas geradoras da real problemática, dentro da matriz neoliberal. Um golpe duro ao princípio de universalidade dos bens públicos e à condição do direito de cidadania. Ou seja, a intervenção social empresarial não é universalizante. Constata-se que estas críticas provêm de um importante raciocínio crítico, porém tautológico, na medida em que circula apenas na crítica ao movimento empresarial, esquecendo-se de que a responsabilidade social empresarial articula-se com a atuação do Estado, dos governos e das comunidades.

Empresários entrevistados para a pesquisa "A Responsabilidade Social das Empresas no Brasil" (Cappellin et al., 2000) apontaram que suas associações estabelecem uma clara distinção entre responsabilidade pública e privada. Mesmo concordando com a idéia de que a elevação dos níveis de escolaridade e a boa saúde dos cidadãos sejam fatores estratégicos para o desenvolvimento das empresas, esperam que a promoção da educação e da saúde seja responsabilidade do Estado e que ele cumpra com sua obrigação. As empresas se tornam promotoras de iniciativas na área social somente quando tais ações podem resultar em externalidades positivas ou em vantagens comparativas para as próprias empresas. 
Portanto, dois fatos incitam outros questionamentos acerca das críticas colocadas. O primeiro fato é que nem todas as empresas realizam a denominada responsabilidade social empresarial e, aquelas que o fazem, muitas vezes engajam-se em projetos em parcerias com o Estado. As próprias empresas colocam a necessidade de se articularem com o Estado, provavelmente, para legitimar suas ações sociais ou em face do reconhecimento de seu próprio limite. Desta forma, o papel do Estado não é dispensável na maioria dessas ações.

O segundo fato refere-se à crítica de que o poder econômico das empresas possa gerar poder social e minar a autonomia e a força integrativa dos atores sociais. Entendo que a própria disputa política e ideológica pela promoção do bem público, entre empresas e o Estado, é intermediada pelos beneficiários desses bens - os cidadãos, as comunidades. Apesar dos seus limites, não acredito na subserviência ou na passividade do papel dos cidadãos no contexto atual.

Portanto, aqui o objetivo é refletir sobre em que medida o investimento em ações sociais do empresariado, configurado através de redes sociais entre o Estado e a sociedade civil organizada, influencia a arena política e pública na demanda pelos direitos de cidadania.

Será que podemos entender que quando esses três atores sociais atuam conjuntamente no espaço público na promoção do bem-estar social estamos observando a emergência uma nova forma de coesão social?

\section{A responsabilidade social empresarial na governação do espaço público}

Conforme Isabel Guerra afirma, assistimos hoje à construção de "novas políticas públicas" produzidas através de uma determinada racionalidade e leitura da realidade social de um conjunto diversificado de atores sociais: por um lado, pela lógica do Estado e, por outro lado, pelos atores em situação de exclusão (Guerra, 2000: 52). Porém, a partir do movimento social empresarial, devemos incluir também os agentes econômicos na lógica dessas "novas políticas públicas".

As empresas têm ultrapassado os limites do privado e avançado no espaço público para construir políticas sociais, em conjunto com governos e movimentos sociais populares. Mesmo que sejam produzidas por um ambiente restrito de empresários, essas políticas têm assumido fortes conexões de negociação da ação coletiva. Nesse sentido, acrescentar os agentes econômicos a essas "novas políticas públicas" é mais um elemento preocupante na dicotomia inclusão/manipulação. 
Portanto, podemos entender que, na modernidade contemporânea, e de acordo com Isabel Guerra:

[...] as políticas públicas são o resultado de processos de negociação em contextos de poder desiguais, funcionando como mecanismos de regulação social e de governação [...], não são factores de dominação ou de emancipação, já que contêm simultaneamente tendências hegemônicas e contra-hegemónicas, não sendo estádios de desenvolvimento, mas dimensões inerentes às formas de constituição da vida social. (ibid.: 53)

Desta forma, nossa atenção deve ser redobrada, já que novos dilemas e desafios são colocados para a produção de políticas sociais, nas quais múltiplas subjetividades coletivas aparecem como responsáveis pela solidariedade social, antes confinada no Estado.

Hoje, observamos que a triangulação da regulação social - entre Estado, mercado e comunidade - se modificou. No âmbito da solidariedade da comunidade, a sociedade-providência se formalizou e ultrapassou os limites do espaço doméstico para alcançar o espaço público. O espaço vazio deixado pelo Estado (ou o seu acentuado recuo) fez com que a sociedade-providência avançasse no espaço público, criando linhas paralelas que se entrecruzam com o Estado-Providência a partir de projetos para o bem-estar coletivo, como observamos na emergência de organizações não-governamentais ou associações de solidariedade social (Santos, 1995). E pelo lado das empresas, elas aproveitaram as fissuras deste espaço e passaram a se interconectar com o Estado-Providência e com essa sociedade-providência, mais formal, discutindo e promovendo seus próprios paradigmas do que seja a questão social, através do investimento social privado.

Esta interconexão de ações sociais tem hoje, no Brasil, sido incentivada pelo próprio Estado. Há que ressaltar que algumas empresas ainda resistem em envolver-se com entidades governamentais na produção de políticas de bem-estar e elaboram autonomamente seus projetos. Contudo, diversos organismos internacionais e agências de fomento econômico têm, no momento, atuado na direção de sensibilizar as empresas a atuar em parceria com governos e comunidade, até mesmo como exigência de contrapartida para financiamento.

Os benefícios do investimento social privado, para as empresas, não é controlado ou mensurado com exatidão. O que existe é uma expectativa empresarial que essas iniciativas se convertam em rentabilidade. As perspectivas empresariais quanto à RSE não são conhecidas antecipadamente, devido ao próprio contexto de incertezas. É na prática e na relação entre 
atores envolvidos, no seio da empresas e no seu ambiente de atuação, com suas contradições e arbitragens, que as ações são determinadas, evoluem ou não, pois os conflitos fazem parte na dinâmica do tecido social. Portanto, é uma escolha política significativa que deve ser analisada dentro de um enquadramento contextual, em que a regulação social atual está envolvida por uma configuração pluralista, polifórmica, policêntrica, portanto, de complexidade.

Não basta isolar o fenômeno da responsabilidade social empresarial e tratá-lo como estratégia maléfica à dimensão política emancipatória. Cabe antes reconhecer que sua ação está relacionada aos vínculos com outras institucionalidades da coordenação social, na medida em que ela se desenvolve em interface com o Estado e com a comunidade na dinâmica da regulação social.

Desta maneira, acredito que as iniciativas sociais empresariais devam ser incorporadas em outro espaço da regulação social. Um outro espaço que atue em simetria com os princípios e valores do Estado-Providência (legitimidade, cidadania e provisão do bem comum) e com os da sociedade-providência (reciprocidade e identidade). Desta forma, defino este outro espaço da regulação social, criado pela expansão da responsabilidade social empresarial, como empresa-providência.

Em princípio, poderíamos acreditar que as ações sociais realizadas pelas empresas seriam nada mais do que ações de uma sociedade-providência que se tornou mais formal, complexa e abstrata. Contudo, a prestação da solidariedade da sociedade-providência, conforme Boaventura de Sousa Santos (1995), não está sujeita a um cálculo econômico, mas é feita nas possibilidades econômicas da teoria da dádiva.

Mesmo que as empresas estejam orientadas pelos valores de solidariedade, reciprocidade e cooperação ao promover políticas sociais, suas ações não são regidas pelo valor da dádiva, como explícito na sociedade-providência, onde o ato de doar vai muito além de qualquer perspectiva utilitarista ou de exclusivismo econômico sobre as trocas sociais. A doação empresarial, apesar de não ser orientada exclusivamente pela maximização do lucro, não pode afetar ou colocar em risco a lucratividade das empresas.

Usar o termo empresa-providência pode ter alguns inconvenientes. $\mathrm{O}$ primeiro é associar às empresas a providência. $\mathrm{O}$ termo providência aliado às empresas pode nos causar um certo desconforto, no sentido em que ele carrega em sua semântica uma idéia religiosa da suprema sabedoria com que Deus conduz todas as coisas. Nesse sentido, usar o termo providência é assumirmos - inconscientemente - que as medidas serão determinadas 
ou inspiradas pela Providência Divina e terá um acontecimento feliz. Isso é ainda mais claro nos países de origem católica, onde Estado e Igreja estiveram por muito tempo associados.

$\mathrm{Na}$ medida em que nos afastamos da idéia maniqueísta do significado de providência, passamos a adotar o termo no sentido de: tomar providência à cerca de; atender às necessidades; dar ou tomar providências; acudir, atender. Assim, os contextos históricos e sociais têm nos mostrado o papel do Estado-Providência e da sociedade-providência na provisão do bem-estar. Contudo, o sentido dado por cada um ao termo providência é seletivo e seu movimento em prover é resultado de diferentes motivações e racionalidades.

A empresa-providência emerge e interpela a regulação social com uma racionalidade híbrida e intersubjetiva, em que valores de rentalidade/eficiência estão embricados com os de solidariedade social. Desta forma, a política social será entendida como atividade privada, não-obrigatória. Mesmo que suas motivações se entrecruzem com o bem-estar da sociedade, o impulso do movimento social empresarial é o de estabelecer o equilíbrio social, contrabalançar, reparar o dano, indenizar e recompensar a sociedade.

Para Hodgson (1994), a empresa não existe apenas num mar de relações de mercado; ela existe também numa rede vital de laços contratuais estabelecidos que são, em parte, criados por ela mesma. Nesse sentido, a confiança e a cooperação são valores importantes na eficiência da empresa. A empresa é, portanto, um locus em que as relações humanas estão em constante desenvolvimento, como instituição social. Isto não quer dizer que para o autor, as empresas capitalistas sejam instituições de beneficiência e filantropia. O que ele afirma é que alguns elementos extra-contratuais, como a lealdade e a confiança (mesmo que pequena) são essenciais ao funcionamento da empresa, pois criam uma relativa estabilidade interna para conviver em ambiente de incerteza e riscos inquantificáveis, que seriam evitados na volatilidade do mercado.

Mesmo concordando que as empresas não são mercado, não podemos perder de vista que elas são a principal instituição do mercado. E que o seu crescimento explosivo influenciou a capacidade de regulação nacional da economia e os mecanismos de regulação dos conflitos entre capital e trabalho, invadindo o princípio do Estado e da comunidade e tendendo a dominálos de forma profunda (Santos, 1999: 89).

Em última instância, podemos entender que a empresa-providência faz parte do "novo espírito do capitalismo" (Boltanski e Chiapello, 2000), na medida em que busca argumentos orientados ao bem comum, incorporando pontos de apoio moral e de dispositivos de justiça no sentido de contribuir para justificar a ordem estabelecida e mantê-la, legitimando os modos de 
ação que são coerentes ao capitalismo. Contudo, é no embate entre forças políticas emancipatórias no enfrentamento da ordem estabelecida que poderemos vislumbrar a transformação social.

\section{4. À guisa de conclusão}

No atual cenário da regulação social, importa compreendermos a relação social produzida na rede de relações entre empresa-providência, Estado-providência e sociedade-providência, na provisão da solidariedade com o bem comum. O uso semântico do termo empresa-providência, em analogia aos outros dois, coloca em jogo a tentativa das empresas de deslocar a relação cliente-consumidor (própria das empresas) para o espaço de cidadania, gerando uma outra relação: a de consumidor-cidadão.

Este conceito de empresa-providência, aqui definido, é o espaço onde se realiza uma atuação política e pragmática (individual e/ou coletiva de empresas) de reconversão de parte do investimento do capital privado em serviços de interesse público e de desenvolvimento social para trabalhadores e comunidades, através de doação, filantropia, parceria de capital, práticas de boa conduta e de responsabilidade social empresarial. Resta ressaltar que essas ações devem estar alinhadas com os objetivos estratégicos das empresas, de seus acionistas e do crescimento sustentado do mercado.

A atuação da empresa-providência tem se dado através de redes sociais e da relação entre o Estado, governos e a comunidade. É desta maneira que avança nas esferas cultural, social, política e das subjetividades coletivas. Captura e absorve tanto os princípios de solidariedade do Estado quanto da comunidade e cria um novo espaço para regular o bem comum. Acredito que, desta forma, alguns conflitos sociais podem ser absorvidos pelo universo empresarial através da provisão das demandas sociais e, consequentemente, poder-se-á criar uma outra forma de solidariedade societária: controlada e domesticada.

Contudo, diante do risco político do investimento social privado enfraquecer o espaço público na luta pelos direitos de cidadania, este só poderá ser enfrentado no palco de discussões entre o Estado - que controla, fiscaliza e protege o bem público -, a comunidade organizada e as empresas. As opções das lideranças políticas nacionais e suas coalizões são aspectos decisivos na definição das políticas sociais a serem implementadas. Ignorar o peso dessas conduções implica isentar os governantes de turno da sua responsabilidade pelas decisões tomadas e pelos seus resultados. Desta forma, o investimento social privado só terá malefícios enquanto houver um Estado e um governo paralítico e uma comunidade alheia aos negócios públicos. 


\section{Referências Bibliográficas}

Ashley, Patrícia Almeida et al. (2000), Responsabilidade social corporativa e cidadania empresarial: uma análise conceitual comparativa. São Paulo: Anais do $24^{\circ}$ Encontro Nacional da ANPAD.

Beghin, Nathalie (2003), A filantropia empresarial: nem caridade, nem direito. Brasília : Departamento de Serviço Social - Universidade de Brasília, Dissertação de Mestrado.

Boltanski, Luc; Chiapello, Eve (2002), El nuevo esprito del capitalismo. Madrid: Akai. Cappellin, Paola (2004), "A igualdade das oportunidades nas relações de trabalho: a ética de reparação antecede o dever de responsabilidade", in Ana Alice Costa et al. (orgs), Reconfiguração das relações de gênero no trabalho. São Paulo: CUT.

Cappelin, Paola et al. (2000), "As organizações empresariais e a responsabilidade das empresas”, in A. Kirschner; E. Gomes; P. Cappellin (orgs.), Empresa, empresários e globalização. Rio de Janeiro: FAPERJ e Relume Dumará.

CES - Conselho Económico e Social (2003), Seminário: a responsabilidade social das empresas. Lisboa: Centro de Documentação e Informação do Conselho Económico e Social, Série Estudos e Documentos.

Cheibub, Zairo B.; Locke, Richard M. (2002), "Valores ou interesses? Reflexões sobre a responsabilidade social das empresas", in A. Kirschner; E. Gomes; P. Cappellin (orgs.), Empresa, empresários e globalização. Rio de Janeiro: FAPERJ e Relume Dumará.

CIOLS - Confederação Internacional das Organizações Sindicais Livres (2001), Una guía sindical sobre la mundializacion (versão electrónica: http://www.icftu.org/pubs/ globalisation).

Comissão das Comunidades Européias (2001), Livro Verde da Comissão Europeia: promover um quadro europeu para a responsabilidade social das empresas. Bruxelas: CCE.

De Swaan, Abram (1992), A cargo del Estado. Barcelona: Ediciones Pomares-Corredor, S.A.

Delgado, Ignácio Godinho (2001), "Empresariado e política social no Brasil", in A. Kirschner; E. Gomes, Empresa, empresários e sociedade. Rio de Janeiro: Sette Letras.

Duarte, Gleuso Damasceno; Dias, José Maria (1986), Responsabilidade social: a empresa hoje. Rio de Janeiro: Livros Técnicos e Científicos.

Friedman, Milton (1985), Capitalismo e liberdade. São Paulo: Nova Cultura.

Galbraith, John Kenneth (1982), O novo estado industrial. São Paulo: Abril Cultural.

GIFE - Grupo de Institutos, Fundações e Empresas (2001), Investimento social privado. Perfil e catálogo dos associados. São Paulo: GIFE.

Guerra, Isabel (2002), "Cidadania, exclusões e solidariedades. Parodoxo e sentidos das 'novas políticas sociais'”, Revista Crítica de Ciências Sociais, 63.

Henderson, David (2001), Misguided Virtue: False Notions of Corporate Social Responsibility. London: Institute of Economic Affairs. 
Hodgson, Geoffrey M. (1994), Economia e instituições: manifesto por uma economia institucionalista moderna. Oeiras: Celta Editora.

Hunter, James Davison (1999), "La guerra cultural americana”, in P. Berger (org.), Los límites de la cohesión social. Conflitos y mediación en las sociedades pluralistas. Barcelona: Galaxia Gutemberg e Círculo de Lectores.

IPEA (2001), A iniciativa privada e o espírito público - um retrato da ação social das empresas. Relatório de pesquisa. Brasília: Instituto de Pesquisa Econômica Aplicada.

Keynes, John Maynard (2002), "Força própria”, Jornal Valor Económico, Cadernos Eu \& Comunidade, Rio de Janeiro, 14 nov.

Offe, Claus (2000), “A atual transição da história e algumas opções básicas para as instituições da sociedade”, in L. C. Bresser Pereira et al. (org.), Sociedade e Estado em transformação. São Paulo e Brasília: ENAP, UNESP e Imprensa Oficial.

Paoli, M. Célia (2003), "Empresas e responsabilidade social: os enredamentos da cidadania no Brasil", in Boaventura de Sousa Santos (org.), Democratizar a democracia - os caminhos da democracia participativa. Rio de Janeiro: Ed. Civilização Brasileira.

Porter, M. E.; Kramer, M. R. (2002), “The Competitive Advantage of Corporate Philanthopy”, Harvard Business Review, december, 56-68.

Santos, Boaventura de Sousa (1995), "Sociedade-providência ou autoritarismo social", Revista Crítica de Ciências Sociais, 42, i-vii.

Santos, Boaventura de Sousa (1999), Pela mão de Alice. O social e o político na pós-modernidade. São Paulo: Ed.Cortez.

Toffler, Alvin (1995), A empresa flexivel. Rio de Janeiro: Record.

Weinstein, Bárbara (2000), (Re)formação da classe trabalbadora no Brasil, 1920-1964. São Paulo: Cortez. 



\title{
Novos espaços produtivos e novas-velhas formas de organização do trabalho: As experiências com cooperativas de trabalho no Nordeste brasileiro
}

\begin{abstract}
Este artigo analisa a nova industrialização do Nordeste brasileiro, resultante de políticas de atracção industrial a partir dos anos 90 e caracterizada por incentivos fiscais a indústrias de uso de trabalho intensivo, como calçados e confecções, e pela indução de organização de cooperativas de trabalhadores para externalizar a produção e reduzir os custos com a mão-de-obra. Esse processo foi mais significativo no estado do Ceará. As cooperativas foram instaladas no interior do estado, com oferta abundante e barata de mão-de-obra sem outras opções de emprego e com inexistência de actividade sindical. Esse processo ocorreu num contexto de reestruturação económica e mudanças políticas de carácter neoliberal do Estado brasileiro, marcado pela abertura do mercado interno às exportações, a desnacionalização de sectores produtivos, a relocalização industrial e a modernização tecnológica.
\end{abstract}

Este $\operatorname{artigo~}^{1}$ pretende analisar a nova industrialização do Nordeste brasileiro, resultante de políticas de atração industrial a partir dos anos 90 , caracterizada por incentivos fiscais a indústrias de uso de trabalho intensivo, como calçados e confecções, e a indução de organização de cooperativas de trabalhadores para terceirizar a produção e reduzir custos com a força de trabalho. Deter-nos-emos no estudo do estado do Ceará, onde esse processo foi mais significativo. As cooperativas foram instaladas no interior do estado, na região semi-árida, com oferta abundante de força de trabalho, sem outras opções de emprego e inexistência de atividade sindical. Esse processo deu-se num contexto de reestruturação econômica e mudanças políticas de caráter neoliberal do Estado brasileiro, marcado pela abertura do mercado interno às exportações. A busca por redução de custos significou eliminação ou desnacionalização de setores produtivos, relocalização industrial e

\footnotetext{
${ }^{1}$ A pesquisa de campo foi realizada entre 1997 e 2000 e entre 2002 e 2004, com visitas a cooperativas, observação do processo produtivo, entrevistas e questionários com dirigentes, trabalhadores e sindicalistas. Teve apoio financeiro da FINEP e CNPq.
} 
modernização tecnológica em busca de competitividade internacional. Para os trabalhadores, a redução de custos significou ataques sistemáticos à regulamentação do mercado de trabalho e a utilização de formas alternativas de utilização da força de trabalho fora das relações salariais, alterando o significado de formas de organização do trabalho que, originalmente, pressupunham a autonomia, participação e posse coletiva dos meios de produção pelos trabalhadores.

\section{Os novos espaços produtivos}

A busca da redução de custos pelas empresas torna a mobilidade espacial um fenômeno global. Áreas antes marginais do processo produtivo, agora são "incluídas" no fluxo de uma economia internacionalizada. Áreas de industrialização antiga, com mão-de-obra treinada e organizada, são abandonadas por áreas que, mesmo sem possuir essas condições, permitem o barateamento do custo do trabalho. Ocorre, então, a ressignificação dos lugares.

Segundo Dupas (1999), dentro do período conhecido como acumulação fordista, mais especificamente no final dos anos 60 e começo dos anos 70, houve uma expansão de indústrias multinacionais em direção à periferia do sistema capitalista, em busca de "lugares" que oferecessem possibilidades de expansão rentáveis de investimento, em contraposição à "rigidez" das relações de trabalho nos países centrais e à força do movimento sindical do período. Esse processo impulsionou a industrialização por substituição de importações em países da América Latina e Sudeste Asiático, fazendo surgir um operariado "moderno" nesses países, com grande capacidade de mobilização.

Com o aprofundamento da internacionalização da economia, fracionam-se as cadeias produtivas com a formação de redes empresariais e o surgimento de empresas virtuais, que criam produtos fabricados, em partes ou em sua totalidade, em empresas menores distribuídas pelo mundo. Ao mesmo tempo em que se desconcentram os espaços produtivos, concentram-se cada vez mais os núcleos de decisões nas chamadas cidades globais (Sassen, 1998) dos países desenvolvidos, que se articulam com cidades globais situadas nos países emergentes. Nessas cidades situam-se os recursos e a mão-de-obra qualificada. Nos demais espaços, distribui-se a produção com trabalho intensivo e mão-de-obra desqualificada, incorporando novos territórios à economia globalizada. A ressignificação do território e sua produção, resultado dos sistemas informacionais, dar-se-ia pela composição de malhas, nós e redes coordenados por empresas. No novo desenho, o Estado e as fronteiras nacionais estariam perdendo o papel em sua determinação. 
Dispersão e concentração das atividades produtivas marcam a nova divisão internacional do trabalho, mesmo considerando que o crescimento das indústrias de informações e a consequente transmissão automática de dados dão a impressão de que o "lugar" não tem importância. O gerenciamento e controle das operações exigem, segundo Sassen (1998: 16), lugares centrais onde é desenvolvido o trabalho globalizado, o qual necessita de vasta infraestrutura física, com a hiperconcentração de determinados meios, tais como telecomunicações, serviços especializados variados exigidos pelas tecnologias de informação, e para o controle e manutenção de uma rede global de fábricas e operações ligadas a serviços e mercados.

Nas últimas décadas do século XX, com o aumento da mobilidade do capital em termos transnacionais, originaram-se novas articulações entre diferentes áreas geográficas, assim como novos papéis a serem desempenhados por esses "lugares". Entre os tipos mais conhecidos de localização para essa produção internacional, estariam os centros bancários off shore e as zonas de processamento de exportações, que assumem configurações distintas conforme o país em que se inserem.

Para Sassen (1998), as cidades permanecem como lugares destinados a certas atividades e funções. Atuam como elos de uma rede, onde o controle econômico e da propriedade situa-se em cidades "globais" que funcionam como pólos de comando da economia mundial, mercados das novas indústrias e lugares de produção das inovações e de concentração de mão-de-obra: de trabalhadores altamente qualificados, a prestadores de serviços dos mais diversos e em relações de trabalho diferenciadas.

A criação de redes controladas pela eletrônica, telemática, enfim, pelas novas tecnologias informacionais, reordena os espaços geográficos (realidade material pré-existente), territorializando ou desterritorializando as sociedades pelas práticas sociais.

$\mathrm{Na}$ periferia desse processo, situam-se cidades e territórios incorporados à produção global, que se tornam estratégicos a partir do barateamento da produção, propiciada por: legislações favoráveis aos investimentos, isenções de impostos, mão-de-obra abundante, barata e desorganizada, com processos produtivos tradicionais, trabalho intensivo e baixa incorporação de tecnologia. A informatização do controle permite às empresas matrizes acesso aos dados das empresas terceiras espalhadas pelo mundo. São espaços reapropriados funcionalmente, espaços dominados que perdem sentido, em termos de significação comunitária.

Para Santos (1999), o território incorpora sistemas naturais, sua base técnica e práticas sociais; assim, não haveria uma desterritorialização, mas uma revitalização do território a partir da mundialização da economia. As 
novas técnicas multiplicariam a produtividade a partir de lugares, e por suas distintas capacidades de oferecer uma produtividade maior ou menor, produtividade esta que deixa de ser atributo de uma empresa, mas que se constitui atributo de lugares. Ao escolher cidades e regiões de um determinado país, as empresas exigem infra-estrutura adequada a seus investimentos, assim como condições políticas adequadas. São zonas de processamento de exportações, em países periféricos, onde as fábricas são implantadas para processar ou montar componentes trazidos de países centrais e reexportadas para esses mesmos países. São fábricas ou maquiladoras, situadas em diversos países que alteram sua legislação para aceitar esse tipo de atividade em seu território. É também a partir dessas condições que os "lugares" disputam a atração de novos investimentos como forma de serem incluídos nos fluxos da economia global.

Segundo Arbix e Rodrigues-Pose (1999), a abertura econômica dos países em desenvolvimento, em tese, traria efeitos positivos na direção de uma maior igualdade inter-regional. Isso pela demanda de trabalho não-qualificado, embora alfabetizado, resultante de economias de exportação, o que acarretaria uma redução das disparidades regionais nos países, considerando a capacidade de cidades ou regiões na formulação de estratégias de competição territoriais exitosas. Todavia, a questão é polêmica, uma vez que a competição pode neutralizar efeitos positivos de uma maior integração econômica.

A partir da abertura econômica brasileira e da formação do Mercosul, o país recebeu uma quantidade de investimentos estrangeiros diretos nunca vistos, entre os quais se destaca a implantação de grandes montadoras de automóveis e de empresas que compõem essa rede produtiva. Desencadeia-se, a partir daí, uma disputa territorial por esses investimentos entre os estados da federação, que será conhecida como "guerra fiscal”. Para Santos (1999), a produtividade e competitividade empresarial transcendem as estruturas internas corporativas e passam a ser atributo dos lugares, que agregam valor aos investimentos. Com isso, a "guerra fiscal" refletiria uma guerra global entre "lugares".

No Brasil do final dos anos 80 , a reestruturação produtiva reduziu radicalmente os empregos com novas tecnologias e formas de gestão, privatização de empresas estatais, deslocamento espacial de indústrias em busca de redução de custos e maior competitividade internacional. Alterou-se a configuração espacial da produção industrial no país com a incorporação de áreas antes marginais a esse processo, que adquiriram nova significação. É nesse contexto que o Nordeste do país se inseriu na "guerra fiscal". Não em busca de grandes montadoras de automóveis, mas na atração de setores de mão-de-obra intensiva como o setor do vestuário, conforme veremos a seguir. 


\section{Guerra fiscal e relocalização industrial}

O setor do vestuário, que engloba confecções e calçados, caracteriza-se pela heterogeneidade e diversidade de seus processos produtivos ditados pela sazonalidade da demanda (Abreu, 1986). Apesar das inovações tecnológicas, normalmente restritas a grandes unidades produtivas, a costura propriamente dita constitui-se em um "gargalo" de produção, exigindo a utilização de grandes contingentes de força de trabalho em razão da multiplicidade de tarefas requisitadas conforme a peça realizada. Com isso, as grandes unidades fabris trabalham com produtos estandardizados, ficando as peças mais diversificadas e que exigem maior detalhamento com pequenas e médias unidades fabris, ou com uma infinidade de ateliês domiciliares, que possibilitam a flexibilidade produtiva exigida pelo mercado e pelas variações da moda. Essas unidades menores podem ou não trabalhar de forma terceirizada e, no seu conjunto, respondem pelo maior contingente de trabalhadores empregados. A relação imediata máquina de costura-operador ainda é predominante no processo produtivo, o que torna o trabalho intensivo uma característica do setor, apesar do avanço das inovações tecnológicas. A subcontratação de trabalhadores domiciliares que realizam tarefas específicas por encomendas é tradicional nesse ramo produtivo, e a novidade, se assim pode ser considerada, estaria na mobilidade espacial das grandes indústrias em busca de menores custos para atender a um mercado cada vez mais globalizado, assim como na utilização de formas de terceirização, até então pouco usuais.

A produção do vestuário é uma das mais globalizadas indústrias, estando presente, de forma simultânea, em mais de 40 países, do sudeste da Ásia à América Latina, Caribe e Europa, capitaneadas pelas TNC - Transnational Corporations, empresas globais que, através de tecnologias informacionais, coordenam a fabricação de produtos em múltiplos locais simultaneamente. Utilizando tecnologias simples, baseadas na relação trabalhador-máquina de costura, são indústrias caracterizadas pela utilização de trabalho intensivo. Sua expansão por países de regiões não industrializadas ou de industrialização recente, resulta na proletarização de trabalhadores engajados originalmente na agricultura ou em atividades não capitalistas, que passam a ser incorporados como força de trabalho industrial. São trabalhadores, mulheres em sua maioria, que passam a constituir uma primeira geração - em grande medida - de trabalhadores de formas assalariadas distintas, sendo vulneráveis às condições de extrema exploração do trabalho (Bonacich et al., 1994).

O caráter assumido por essas indústrias reflete uma forma global de guerra fiscal e de arranjos legais que criam distintos formatos de organização 
e gestão da produção. Uma delas são as fábricas maquiladoras. Surgidas inicialmente no México, trabalham com produção em massa, lotes padronizados e exigências de produção simples. Montam peças básicas de roupas como jeans, roupas íntimas, uniformes industriais, etc. Utilizam insumos norte-americanos e maquinaria norte-americana e montam peças que são exportadas para o mercado norte-americano. Situam-se na fronteira com os EUA e utilizam basicamente o baixo custo da mão-de-obra local. O percentual de insumos mexicanos é mínimo. ${ }^{2}$

Essas maquiladoras se espalham pela América Central e Caribe, através de empresas asiáticas que se instalam no país aproveitando as cotas de exportação para os EUA. Beneficiam não só do baixo custo da mão-de-obra e ausência de qualquer regulação do mercado de trabalho desses países, mas também da repressão da atividade sindical. No México, como na América Central e no Caribe, representam percentual significativo da mão-de-obra utilizada no setor industrial, setor este que, entretanto, não possui qualquer caráter multiplicador. Situadas em Zonas Especiais de Processamento de Exportações (ZPE), beneficiam de incentivos fiscais e utilizam o território apenas como base de montagem de produtos, raramente agregando qualquer valor local a eles, ou transferindo qualquer tipo de tecnologia.

No Brasil, por ter um mercado de trabalho "formalmente" regulado, embora com grande flexibilidade no que se refere à demissão de pessoal, além da pouca observância efetiva da legislação do trabalho, as ZPE nunca saíram do papel. Nos anos 70, criou-se a única zona franca do país: Manaus, no interior da região amazônica. Uma zona franca peculiar voltada para a montagem de produtos e exportação para o mercado interno.

A chamada "era Collor", nos anos 90, marcou a entrada do país nos tempos neoliberais da economia globalizada. O parque industrial brasileiro passou por um processo de reestruturação para se adaptar às exigências impostas pelo processo de globalização dos mercados. A busca da competitividade, através da modernização tecnológica, qualidade, redução de custos, implicou redução significativa do emprego industrial, desnacionalização de setores, encerramento de unidades fabris e desconcentração espacial da produção.

A busca de menores custos - leia-se mão-de-obra barata e pouco organizada - tem se refletido no aumento da mobilidade espacial das empresas para outras regiões do país. A saturação e degradação de áreas urbanas como São Paulo e o grande $\mathrm{ABC}$ tem levado, já há algum tempo, à transfe-

\footnotetext{
${ }^{2}$ Segundo Gereffi (1997), antes do NAFTA as empresas maquiladoras não tinham nenhuma relação com produtores de têxteis ou cadeias varejistas mexicanas.
} 
rência de unidades fabris para o interior do estado e mesmo para outros estados, atraídas por melhor infra-estrutura, baixo custo dessa infra-estrutura, incentivos fiscais de prefeituras, proximidade de mão-de-obra escolarizada e qualificada, baixa atividade sindical, entre outras vantagens.

Esse movimento de desconcentração industrial, entretanto, não é recente. Segundo L. Guimarães Neto (1995), o processo inicia-se a partir da segunda metade da década de 70 por meio da transferência de capitais privados e estatais das regiões mais industrializadas do país para as mais "atrasadas". Esse período, que o autor denomina de "integração produtiva", substitui o anterior de "articulação comercial" existente entre as várias regiões do país, então com a presença dos grandes grupos econômicos em praticamente todas as regiões do país. A "articulação comercial" caracterizou o período dos grandes projetos da área da SUDAM e da SUDENE, que implicou a implantação de numerosas unidades fabris nas regiões abrangidas por essas instituições de planejamento, e o crescimento, por exemplo, do Nordeste em taxas superiores à média nacional entre 1970-1995 (SUDENE, 1997).

A crise do Estado brasileiro e suas políticas de proteção industrial, seu esgotamento fiscal nos anos 80 com a sucessão de crises econômicas e altas taxas de inflação, num contexto internacional de eliminação de barreiras nacionais à circulação de mercadorias, levou ao abandono das políticas centralizadas de planejamento econômico, industrial, ou até, podemos dizer, de qualquer planejamento. Nesse contexto, cada estado da federação (uns mais do que outros) passou a disputar investimentos industriais com as vantagens locacionais de seu território frente a um mercado globalizado. $\mathrm{Na}$ "guerra fiscal" desencadeada entre os diversos estados da federação, os incentivos incluem a renúncia fiscal, o fornecimento de infra-estrutura, preços subsidiados (como tarifas de água e energia elétrica) à montagem da fábrica e mesmo o pagamento de salários dos trabalhadores por determinado tempo. Esse processo, se, num primeiro momento, vai dinamizar a desconcentração industrial com prejuízo de áreas industriais tradicionais, como a região metropolitana de São Paulo - saturada em termos de população e infra-estrutura nos anos 90, com o aprofundamento da abertura econômica -, vai atingir outras áreas que irão assistir o encerramento de unidades fabris, como o Vale dos Sinos, no Rio Grande do Sul, com a guerra fiscal assumindo um perfil mais setorizado.

O novo impulso industrializante no Nordeste, nos anos 90, respondeu à lógica de incorporação de territórios numa economia global e a essa disputa por novos investimentos. Sem cacife em termos de infra-estrutura, capital, além da distância dos mercados consumidores, a guerra fiscal empreendida pelos estados nordestinos dirigiu-se para os setores de trabalho intensivo 
situadas no Sul-Sudeste do país, afetados com a liberação de importações: têxteis, calçados, confecções, alimentos.

A mão-de-obra abundante, pouco escolarizada e sem grande tradição industrial, nunca foi obstáculo à instalação de novas indústrias na região. Deve-se ressaltar que, a partir dos anos 70, o Estado investiu numa rede de universidades federais, que tem garantido mão-de-obra qualificada e mesmo criado núcleos de alta tecnologia. A importação de mão-de-obra qualificada nos projetos dos anos 70 deu lugar a técnicos da própria região, ficando, todavia cargos de supervisão, de uma forma geral, com funcionários transferidos das matrizes do centro-sul do país, ou do exterior.

No final dos anos 80, com o esgotamento da política de industrialização regional, caracterizada pela formação de distritos industriais próximos às capitais dos estados e operacionalizada pela SUDENE, os vários estados nordestinos passaram a desenvolver políticas próprias de atração de novos investimentos. Essas políticas têm resultado na instalação de novas fábricas em busca de redução de custos e maior competitividade internacional, beneficiadas por generosos incentivos fiscais dos governos locais. A renúncia fiscal é justificada pela dinamização econômica provocada pela chegada de novas fábricas e pelo número de empregos diretos e indiretos que acarretam, não significando, na versão oficial, perda de arrecadação ou prejuízos. Ao contrário, haveria aumento com a maior circulação monetária e o crescimento da massa salarial. Haveria, então, junção dos interesses empresariais de barateamento de custos com os interesses governamentais voltados ao desenvolvimento socio-econômico.

Numa região maioritariamente situada no semi-árido, que exige grandes investimentos de infra-estrutura e boa vontade política na resolução de suas mazelas econômicas e sociais, a indústria é vista como solução de curto prazo e menores custos. Dessa forma, os governos dos estados passam a oferecer incentivos fiscais, constroem-se ou reformam-se rodovias, portos e aeroportos, para garantir as condições básicas da produção industrial. O Estado continua garantindo as condições de acumulação e reprodução do capital, agora de forma descentralizada. Eliminam-se as tentativas de planejamento, consideradas obsoletas, assim como as políticas voltadas à reprodução da força de trabalho que caracterizavam o período anterior. As cidades receptoras das novas indústrias continuam sem saneamento básico, sem habitação e demais condições básicas necessárias à qualidade de vida. Mas postos de trabalho são criados e uma circulação monetária praticamente inexistente em cidades perdidas nos sertões produz novos consumidores, integrando-os, pelo menos temporariamente, no mercado globalizado. 
A possibilidade de abaixamento dos custos com mão-de-obra em níveis considerados imbatíveis, como os "chineses", foi percebida como a oportunidade de recuperação da competitividade internacional nos setores que perderam mercados, com a entrada de produtos importados a baixo custo: calçados e confecções. Dentro do "novo" modelo implementado, foram privilegiados os setores industriais caracterizados por trabalho intensivo. E, para baixar mais ainda o custo da mão-de-obra, foi elaborado um modelo arrojado, que aliava a interiorização industrial com a instalação de unidades em áreas de economia de subsistência, com uma forma "inovadora" de organização do trabalho: as cooperativas de trabalhadores.

As cooperativas foram constituídas como qualquer outra empresa capitalista. A diferença estaria no controle formal dos meios de produção pelos trabalhadores e em sua gestão do trabalho. Como foram organizadas para funcionarem terceirizadas, funcionavam de fato como setores de empresas.

\section{A atração de investimentos industriais na década de 90}

O Ceará foi o estado do Nordeste que desenvolveu uma política mais agressiva de atração de investimentos industriais nos anos 90, dentro da chamada "guerra fiscal" que vigorou até 2002.

O Estado passou a investir nos setores industriais afetados diretamente pela concorrência internacional provocada pela abertura econômica iniciada no governo Collor: confecções, calçados, metalurgia e eletroeletrônicos. Enviados do governo procuraram empresas do sul-sudeste do país, oferecendo uma série de vantagens para se transferirem para o Ceará: infra-estrutura, prédios, isenção fiscal, mão-de-obra abundante, treinamento e qualificação de trabalhadores, baixa organização sindical desses trabalhadores e a possibilidade de terceirização da produção em cooperativas. O mecanismo utilizado pelo estado era o FDI - Fundo de Desenvolvimento Industrial, com recursos da arrecadação tributária do estado. Com esse mecanismo, os investidores recebiam um financiamento, após quitação mensal do imposto devido, que chegava a $75 \%$ do valor pago ${ }^{3}$ para fábricas localizadas fora da Região Metropolitana de Fortaleza. Esse empréstimo previa ainda um abatimento até $75 \%$ do valor devido e até 15 anos para pagar, representando um subsídio de $56 \%$. Além disso, as empresas recebiam incentivos para a importação de máquinas e equipamentos por meio do não pagamento do Imposto de Circulação sobre Mercadorias sobre essas importações. Quanto maior a distância da capital, maior a quantidade de incentivos oferecidos.

${ }_{3}$ Para empresas situadas na Região Metropolitana de Fortaleza esse valor caía para 40-45\% em média. 
A atração de indústrias foi pensada para evitar a excessiva concentração do modelo anterior (embora a Região Metropolitana de Fortaleza continue sendo a mais beneficiada), assim como foram estudados os setores para os quais o estado teria um atrativo diferencial. Começou-se a analisar setor por setor industrial, criando-se uma ação estratégica objetivando a atração de cadeias produtivas selecionadas.

O setor têxtil estava bem modernizado tecnologicamente, existindo no estado um pólo de fiação; o setor de confecções estava consolidado, apontando para a vocação "natural" do estado. ${ }^{4}$ Entretanto, o fio ia para o sul-sudeste do país ou para o exterior, transformava-se em tecido plano ou malha, retornando para ser confeccionado no Ceará, havendo claramente a possibilidade de atrair toda cadeia produtiva têxtil para o estado. Uma das primeiras tarefas foi, então, a atração de indústrias âncoras do setor têxtil, que funcionariam como chamariz: novas indústrias viriam pela presença de empresas importantes do setor.

Outro setor visado foi o de calçados, grande absorvedor de mão-de-obra e passando por dificuldades no sul-sudeste do país. A equipe de governo contava com técnicos com experiência no exterior e conhecimento dos problemas decorrentes da dificuldade de automação de fases da produção e a necessidade de contar com mão-de-obra barata para garantir competitividade. A idéia presente na atração de novas indústrias, diferentemente do que ocorria no período anterior, estava na captação, não apenas de fábricas isoladas, mas da cadeia produtiva do setor, com a formação de clusters em regiões do estado.

Em termos espaciais, o conceito de pólo foi substituído pelo de interiorização industrial e de formação de distritos industriais de menores dimensões através de incentivos fiscais. Assim foram criados raios de 50, 100, 150, $200 \mathrm{Km}$ em torno de Fortaleza, ao longo das estradas, para a implantação de infra-estrutura industrial. Começa-se com a industrialização de Horizonte, Pacajus na região metropolitana de Fortaleza, até chegar às áreas industrializáveis do Cariri, no sul do estado, e Sobral, no noroeste.

A agressiva política de captação de recursos e investimentos voltados para a interiorização da industrialização levou em consideração as poucas possibilidades de atividades agrícolas e pecuárias no semi-árido, que compõe a quase totalidade do território cearense. A indústria se constituiria na possibilidade, juntamente com o turismo, de desenvolvimento econômico

\footnotetext{
${ }^{4} \mathrm{O}$ setor têxtil e de confecções foi um dos mais beneficiados com investimentos industriais no estado ainda no período da SUDENE. No final da década de 80 o Ceará já se destacava como pólo têxtil e de confecções.
} 
do estado, que, progressivamente, tornou-se líder em termos do montante de investimentos na região, transformando suas históricas desvantagens econômicas, espaciais e populacionais em vantagens no novo contexto da globalização dos mercados.

\section{Incentivos fiscais e redução de custos com a mão-de-obra: as coopera- tivas de trabalho}

Da mesma forma que as novas diretrizes do processo industrializante estadual resultaram dos estudos da equipe governamental dos diversos setores, e das possibilidades de atraí-los para o estado dentro da perspectiva de um mercado globalizado, a terceirização em cooperativas de trabalho teve a mesma matriz.

A idéia de desconcentração da indústria teve como fundamento o novo contexto da produção industrial: a redução do tamanho da fábrica, o enxugamento da empresa com setores da produção terceirizados e as possibilidades de dinamismo econômico de pequenos distritos industriais. Para a equipe governamental, a matriz fiscal tributária e a parafernália de taxas, alvará, impostos existentes e a legislação trabalhista se constituíam em elementos inibidores da produção, por aumentar os custos da mão-de-obra. Com as dificuldades inerentes à mudança da legislação federal, o estado poderia induzir formas de terceirização que barateassem custos e se tornassem um elemento a mais no "mix" de incentivos para atrair novas indústrias.

Nesse quadro, recuperou-se a idéia de cooperativa, mais precisamente de cooperativa de trabalho, uma novidade na região. Apesar do fracasso histórico das cooperativas agropecuárias locais, implementadas com o aval da SUDENE, principalmente na década de 70 (Rios, 1979), considerou-se a possibilidade de criar grupos associativos autônomos para o trabalho urbano industrial em áreas sem nenhuma tradição industrial e, menos ainda, associativa. A idéia nova estaria na indução da terceirização, através de uma política de governo, segundo a qual o Estado treinaria os trabalhadores e a empresa parceira proveria os dois elos que faltavam nas atividades produtivas de pequeno porte: a tecnologia - o aperfeiçoamento dos produtos e processos - e o acesso ao mercado. Isso evitaria repetir resultados de programas de geração de renda, nos quais criavam-se pequenas unidades de produção desvinculadas das necessidades dos mercados. Como antecedente, o governo cearense tinha implantado instrumentos que favoreciam o suprimento desses elos: os palácios da microempresa e as feiras de negócios, que procuravam facilitar o acesso da micro-empresa aos mercados mais modernos e o feed-back desses mercados - o aperfeiçoamento dos produtos e dos 
processos. A partir dessa experiência, surgiu o desenvolvimento do modelo associativo induzido, em que a empresa parceira repassaria tecnologia e estabeleceria o elo do mercado. Dessa forma, a cooperativa seria fruto do esforço governamental de favorecer as atividades de pequeno e médio porte. A tendência de as empresas explorarem ao máximo o trabalho nas cooperativas, seria contrabalançada pela atuação do Estado como mediador e fiscalizador do processo.

As cooperativas de trabalho, dessa forma, integravam a estratégia governamental para reforçar e favorecer um fator que já era favorável na atração de empresas para o Ceará: a mão-de-obra barata. Soma-se a esse fator a possibilidade de terceirizar partes do processo ou o processo todo em cooperativas, eliminando custos com obrigações trabalhistas. Mesmo que isso tenha ferido a concepção de cooperativa vinculada à livre organização dos trabalhadores, o modelo possibilitaria atrair empresas que, de outra forma, possivelmente não iriam para o estado e para cidades do interior, se tivessem que enfrentar custos com obrigações trabalhistas. O caráter polêmico da proposta, assumido pelo governo estadual, estava na flexibilização de fato da legislação trabalhista, de forma pouco ortodoxa, através de um artifício - o trabalho associado. Esse artifício, todavia, foi visto, pelo menos inicialmente, em suas consequências positivas - a geração de empregos e renda, a desconcentração da atividade industrial, sendo assim favorável aos trabalhadores, desconsiderando uma legislação trabalhista considerada arcaica frente às necessidades do mundo da produção e do trabalho.

Para o governo cearense, a implantação de cooperativas era um processo lento que exigia mudanças culturais, principalmente em se tratando de trabalhadores sem qualquer qualificação ou experiência de trabalhado associado. Dessa forma, sua implantação pressupunha uma atuação estatal vista como "moderna" ao largo de políticas paternalistas voltadas à população carente. A proposta era fornecer as condições para que os trabalhadores adquirissem plena autonomia. O Estado não daria dinheiro a fundo perdido para as cooperativas. Estas não possuíam capital inicial, nem capacidade tecnológica, muito menos equipamentos ou instalações. Partindo desses dados, o Estado construiu galpões que eram cedidos para as cooperativas, mas permaneciam como sua propriedade e arrumava a parceria para as cooperativas. As empresas "parceiras” forneciam a matéria prima (no geral, couro cortado), às vezes equipamentos, e as cooperativas geralmente faziam o acabamento de produtos (montagem de sapatos) com contrato por tempo determinado. Cabia ainda ao estado arregimentar mão-de-obra sem qualificação e treiná-la, oferecendo uma bolsa-treinamento. A proposta da política estatal era acompanhar as cooperativas, oferecendo a assistência técnica 
necessária, investindo na formação cooperativista e criando uma "cultura" de trabalho autônomo, numa população sem nenhum contato anterior com trabalho assalariado.

Além da explicação do fundamento da cooperativa induzida - porque formada por trabalhadores sem capital monetário e cultural - a cooperativa se justificaria enquanto proposta de formação de mini-distritos na zona rural, no semi-árido nordestino, que exigiriam investimentos em infra-estrutura, como tratamento de afluentes, energia, etc., e seria uma forma eficaz de acabar com a pobreza. Com a terceirização em cooperativas, cidades que, de outra forma, não atrairiam indústrias, passariam a sediar centros de distribuição das empresas que terceirizariam a produção criando pequenos núcleos de industrialização.

Dessa forma, a atuação estatal como indutor do processo estaria justificada, pragmaticamente, a partir da perspectiva do desenvolvimento potencial que acarreta, desconcentrando espacialmente a atividade industrial, mantendo a população nas cidades, evitando que migrassem para a capital.

Alguns grupos empresariais do setor calçadista instalaram unidades industriais no interior do estado e na região metropolitana de Fortaleza, beneficiando dos incentivos fiscais, mas utilizando trabalho assalariado em suas unidades industriais. Outras empresas instalaram no estado apenas centros de distribuição trabalhando com produção totalmente terceirizada em cooperativas. A implantação de unidades montadoras sobre a forma de cooperativa não envolveu a utilização de insumos locais nem objetivava o consumo local, apenas a mão-de-obra local. Mesmo assim, produziram significativos impactos locais.

\section{As cooperativas de calçados}

Como resultado das políticas estaduais de atração da cadeia produtiva couro-calçadista, a partir de 1995-1996 começaram a instalar-se as cooperativas de calçados, com a abertura de filiais de indústrias do sul do país no interior do estado. Entre elas, destacam-se as instaladas nos municípios de Itapajé, Canindé, Santa Quitéria, Itapipoca, Crateús, Queixeramobim, Iguatu, municípios situados no sertão central do Ceará, com uma economia voltada a agricultura de subsistência e criação de pequenos animais, com produção comercial de castanha de caju e algodão de sequeiro.

As indústrias calçadistas que se instalaram terceirizando a produção em cooperativas concentraram a produção em grandes unidades fabris, utilizando entre 300 a 3.000 trabalhadores cada. As empresas mantinham nas cidades um galpão próprio, onde funcionavam o almoxarifado, o depósito e o escritório, ao lado dos prédios das cooperativas. 
Todas as empresas mantinham funcionários próprios, responsáveis pela supervisão e controle de qualidade. Os demais eram associados. Eram os "gaúchos" (trabalhadores oriundos do sul do país), que passaram a compor o cenário dessas cidades, mais acostumadas a expulsar sua população do que a receber migrantes. Efetivamente, esses funcionários dirigiam as cooperativas. Os presidentes e as diretorias eleitas pelas cooperativas possuíam um papel formal de intermediação entre os cooperativados e os funcionários da empresa. Seus conhecimentos de cooperativismo não diferiam muito daquele dos demais trabalhadores. Ficavam, todavia, com o trabalho "sujo" - a aplicação das regras disciplinares no trabalho: controle de presença, atrasos, faltas, exclusões, etc.

Embora sem um Centro de Treinamento específico, o governo do estado pagava uma bolsa mensal (equivalente a um salário mínimo) pelo período de dois meses para o treinamento dos trabalhadores. Posteriormente, esse treinamento passou a ser realizado sob responsabilidade das próprias cooperativas, supervisionadas pelas fábricas. O recrutamento de trabalhadores passava pelo escritório das empresas, que encaminhavam os trabalhadores para as cooperativas.

Os sapatos, sandálias e tênis, de grifes internacionais, eram exportados para o mercado norte-americano e europeu, através de empresas holdings. As empresas exportadoras, por sua vez, também supervisionavam a produção das cooperativas através de visitas eventuais. As máquinas utilizadas eram das fábricas, cedidas em comodato para as cooperativas, e tinham de 10 a 30 anos de uso. O controle da produção era todo informatizado e controlado pelas fábricas do Rio Grande do Sul, que estabeleciam as metas de produção e supervisionavam, com seus funcionários, as fases da produção, o total produzido, a qualidade, a matéria-prima necessária, a exportação. A matéria-prima vinha do Sul-Sudeste do país, ou mesmo do exterior (quando o câmbio estava favorável).

Nas cidades em que atuavam, eram as maiores empregadoras, com grande impacto no comércio local, através do crescimento do consumo pela inclusão de uma significativa parcela dos trabalhadores na economia monetária, antes praticamente inexistente. Em termos urbanos, algumas cidades tiveram seus melhores bairros ocupados pelos funcionários das empresas que supervisionavam as cooperativas e passaram a demandar melhores serviços, constituindo-se numa classe média local.

A vinda desses funcionários para cidades cearenses não se deu sem conflitos. Para gerir - indiretamente - as cooperativas e para supervisioná-las, operários qualificados e semi-qualificados foram transferidos para essas cidades, com maiores salários, criando uma aristocracia operária, branca, 
loira e com direitos. Eram trabalhadores assalariados das empresas em contraposição aos trabalhadores das cooperativas, em tese, donos do negócio. Aos estereótipos tradicionais somou-se a diferenciação funcional: os gaúchos mandavam e tinham direitos sociais observados, embora não fossem os donos do capital, apenas seus prepostos.

No trabalho existia uma hierarquia dentro da cooperativa. Os gaúchos eram técnicos e trabalhadores qualificados. Em algumas, a bata azul, verde ou amarela estabelecia a hierarquia entre funcionários supervisores e os cooperados.

Gaúchos ou nativos, funcionários e mesmo alguns presidentes de cooperativas agiam como gerentes de uma empresa comum, fazendo questão de demarcar sua situação diferenciada. Mesmo quando cooperativados e ganhando bem acima da média dos trabalhadores, se percebiam como assalariados da empresa e, para ela, prestavam lealdade.

O caráter polêmico das cooperativas resultou, no Ceará, em campanha promovida pela imprensa local, em 1997, com apoio de sindicatos e da Pastoral Operária da Igreja Católica, contra as cooperativas, na instalação de comissões de inquérito na assembléia legislativa e na instauração de processos na justiça do trabalho. As denúncias recebidas pelos sindicatos acerca das condições de trabalho nas cooperativas serviram como documentação às comissões de inquérito referidas. $\mathrm{O}$ sindicato dos sapateiros de Fortaleza (capital do estado) organizou carreatas em algumas cidades do interior, denunciando o que chamaram de "cooperfraude", resultando em conflitos com autoridades locais e proibições, por parte das empresas, de os trabalhadores cooperados se manifestarem. As carreatas, contudo, não chegaram a mobilizar trabalhadores das cooperativas que, embora concordassem com as reivindicações de direitos trabalhistas defendidos pelo sindicado, temiam por seus postos de trabalho, caso as empresas fossem embora e as cooperativas fechassem.

Entretanto, denúncias crescentes sobre as condições de trabalho - grandes galpões com ventilação precária, problemas sanitários, falta de equipamentos de segurança, autoritarismo dos "empregados" das fábricas, exclusões arbitrárias de associados - levaram a uma maior fiscalização da delegacia e procuradoria do trabalho.

Como resultado dessa fiscalização, houve situações de reversão de cooperativas de produção para empresa regular com trabalho assalariado, a adequação de cooperativas irregulares e o encerramento de outras. $\mathrm{O}$ governo cearense parou de incentivar a instalação de novas cooperativas. $\mathrm{O}$ ônus político começou a ficar muito pesado, já que o próprio Estado estava sendo acusado de desrespeitar a legislação. 
Em 2004, após dez anos de implantação do modelo de cooperativas para terceirização industrial, apenas duas grandes empresas mantinham cooperativas no estado. Isto menos por questões de ordem trabalhista do que de ordem fiscal. O fim dos incentivos fiscais e o não cumprimento pelo governo do estado de devoluções previstas no Fundo de Desenvolvimento Industrial fizeram com que parte das empresas encerrassem ou transferissem a produção para outros estados ou regiões do país.

Para os trabalhadores, as cooperativas significaram, na maioria dos casos, o primeiro "emprego" institucionalizado com ganhos regulares, a proletarização efetiva de um contingente de trabalhadores de origem rural ou mesmo urbana sem ocupação anterior definida.

A reação sindical, aos poucos, foi arrefecendo e, nos municípios, as diversas correntes políticas passaram a defendê-las como forma de manutenção de empregos. Da mesma forma, os trabalhadores não se sensibilizaram com o discurso sindical combativo dos primeiros tempos. A não ser quando as empresas começavam a suspender encomendas, comprometendo o funcionamento das cooperativas e os ganhos dos trabalhadores. Em situações de encerramento e crise, os trabalhadores entravam na justiça reivindicando direitos. Em outras situações, as reclamações mantinham-se no cotidiano do trabalho.

Com a multiplicação de cooperativas em outras regiões do país, mudou a atuação dos sindicatos com relação a elas, assumindo em algumas situações a sua própria organização, mas procurando garantir maior controle dos trabalhadores mesmo em situação de terceirização e desenvolvendo políticas de esclarecimento e educação cooperativa. A posição dos sindicatos vincula-se à discussão das centrais sindicais sobre cooperativismo e economia solidária, com posições distintas e atuação diferenciada nas diferentes regiões do país e municípios. No Ceará, a posição oficial do sindicato da capital do estado foi de combate às chamadas falsas cooperativas, pouco atuando junto aos trabalhadores cooperativados no sentido de uma educação cooperativista. O embate era e continua sendo pelo assalariamento.

\section{O trabalho e o local}

Mesmo com as diferenças entre os estados na guerra fiscal, pode-se dizer da existência de situações comuns que apontam para um "modelo" na atração de investimentos industriais, que teve no Ceará a política mais elaborada: a) renúncia fiscal; b) infra-estrutura industrial com fornecimento de galpões, energia elétrica, rodovias, modernização de portos e aeroportos; c) seleção de setores industriais de utilização de trabalho intensivo; d) financiamento do treinamento de trabalhadores; e) utilização de cooperativas de trabalho como artifício para redução de custos com a mão-de-obra. 
Esse "modelo" é aproximativo. Outros estados tentaram, sem sucesso, atrair empresas com organização de cooperativas. Quanto aos demais incentivos, o resultado parece ter sido positivo. Junto com o Ceará, a Paraíba e a Bahia tornaram-se grandes produtores de sapatos, depois do Rio Grande do Sul e São Paulo nos anos 90.

A análise do modelo cearense de instalação de cooperativas possibilita perceber o grau de detalhamento a que chegou a política de atração industrial do estado através de incentivos à instalação de unidades fabris em cidades sem outra atividade econômica significativa; a tentativa de envolvimento da comunidade local na proposta e de várias instâncias governamentais e não governamentais; a profissionalização da mão-de-obra vinculada a projetos específicos; a manutenção dos trabalhadores em seus lugares de origem evitando a migração para as "inchadas" capitais regionais com todas as suas conseqüências sociais.

Todavia, ao lado das boas intenções, características negativas permearam a proposta, ao envolver um dos parceiros - os trabalhadores - de forma desigual. Enquanto as vantagens para as empresas e municipalidades estariam na redução de custos de produção, na instalação de unidades industriais em municípios e maior arrecadação tributária - nem tanto diretamente, dados os incentivos, mas indiretamente, pelo aumento do consumo - para os trabalhadores restou a lógica do "isso é melhor que nada". Ou seja, a renúncia aos direitos sociais básicos que caracterizam o trabalho assalariado, sem a contrapartida efetiva da propriedade ou da gestão coletiva da cooperativa. E uma relação de desconfiança inicial, o que tornou os trabalhadores um parceiro reticente.

Concretamente, as cooperativas constituíram-se nos únicos empreendimentos industriais em algumas cidades do interior da região, mesmo que utilizando do local apenas a mão-de-obra. Instaladas em cidades de 10.000 a 60.000 habitantes, criaram de 300 a 3.000 empregos diretos e tiveram um impacto considerável na economia desses municípios, cujas atividades se limitavam à agricultura de subsistência. Não existem, ainda, indicadores sociais que apontem as mudanças resultantes desses empreendimentos. Entretanto, o trabalhador passou a consumir no mercado local bens materiais e simbólicos a que antes não tinha acesso.

Uma segunda consideração permite entender a atuação contraditória do Estado, seja como executor das leis, seja como o primeiro a desconsiderar essas mesmas leis. No Ceará, como em outros estados da região, e no país como um todo, o discurso do novo é o discurso da modernidade representada pela flexibilização das relações de trabalho, o que justificaria a utilização de artifícios para escapar da legislação e valorizar mudanças nas formas de uti- 
lização da mão-de-obra. Esse discurso foi repetido pelos media, que destacaram que os ganhos do trabalhador flexível seriam maiores que os do trabalhador assalariado, além de mais barato para a empresa. Enfim, o trabalhador utilizaria melhor seu dinheiro do que o Estado regulador. Assim como seria o responsável por sua empregabilidade. O discurso governamental fundamenta-se no atribuído obsoletismo da CLT frente às mudanças na produção e a necessidade de se eliminarem os entraves burocráticos que só dificultariam o acesso ao emprego. Tudo em nome da competitividade internacional.

Parte-se do princípio de que os países avançados flexibilizaram suas relações de trabalho e que o Brasil estaria atrasado nesse processo. Desconsidera-se que a flexibilização nos países centrais é diferenciada, mantendo ainda forte a presença sindical nas determinações do contrato de trabalho. No Brasil, ao contrário, desde 1966 podemos falar de relações flexibilizadas. Quando o regime militar eliminou a indenização por tempo de serviço e a substituiu pelo FGTS, extinguiu-se qualquer limite às demissões, estando flexibilizadas as contratações e demissões. Argumenta-se, contudo, que seu custo é alto pela incorporação de obrigações sociais, logo essas deveriam ser eliminadas.

No caso das cooperativas, sua organização evidencia a utilização deste formato como artifício para descaracterizar o trabalho assalariado. Ao se instalarem em áreas socialmente problemáticas, onde a precariedade das condições de vida e de trabalho constitui-se em norma e não em exceção, aparecem em grande medida como "solução possível" à miséria circundante, à migração para as grandes cidades, enfim, como uma política social num contexto de busca da competitividade internacional, abaixamento de custos pelas empresas e grande mobilidade espacial. E nesse encontro que novos "lugares" são apropriados pelo capital e surgem "novos proletários" sem direitos, sem salários e com poucas perspectivas.

Uma terceira consideração diz respeito ao caráter contraditório dessas cooperativas "pragmáticas", sem autonomia do trabalho, com um trabalhador coletivo "autônomo" que quer ser assalariado. A organização de cooperativas em lugares sem tradição organizativa dos trabalhadores não significou que estes não reivindicassem seus direitos a partir do momento em que se constituíram como atores coletivos. A identificação empresa/cooperativa tirou desta qualquer forma de autonomia e o trabalhador não se reconheceu enquanto participante, mas como logrado em seus direitos. Tal como o trabalhador de uma fábrica comum reage à organização do trabalho, sobre a qual pretensamente decide, para reivindicar direitos.

Falsas cooperativas, portanto? Trabalho assalariado disfarçado? Ou cooperativas pragmáticas? Legalmente, parte das cooperativas estava dentro do que 
rege a legislação do setor e recebia apoio da Organização Estadual de Cooperativas que ressaltava a necessidade de modernizar o cooperativismo, inseri-lo no mercado, trabalhar gerencialmente. A Organização das Cooperativas Brasileiras e as Organizações Estaduais de Cooperativas difundem os princípios cooperativistas e têm tido atuação controversa no debate acerca das cooperativas de trabalho e de sua utilização para mascarar situações de assalariamento. No geral, colaboraram na organização de cooperativas no Nordeste e em outras regiões do país, com cursos de cooperativismo que pouco acrescentaram aos trabalhadores. Por outro lado, defendem-se afirmando não possuírem poder de fiscalização sobre as cooperativas, o que as exime de co-responsabilidades em algumas cooperativas consideradas fraudulentas. O discurso é o da viabilidade da cooperativa no mercado, estando pouco vinculadas a propostas políticas de autonomia dos trabalhadores, o que pode ser atribuído, entre outros fatores, à maior experiência das OCE na organização de cooperativas de créditos e de produtores rurais e o crescimento relativamente recente das cooperativas de produção e trabalho no país.

Ao caráter visto como fraudulento presente nesse formato de cooperativas de produção, podem acrescentar-se problemas organizacionais inerentes às cooperativas de trabalho em geral, organizadas por ou para trabalhadores com pouca qualificação, sem nenhuma cultura organizativa anterior e que são recrutados por programas de desenvolvimento, de geração de renda ou políticas de atração de investimentos, que apresentam o que o "lugar" tem de diferencial: a mão-de-obra barata e desorganizada. O caráter "voluntário" da participação do trabalhador inexiste, refletindo a ausência de opções no mercado de trabalho local. Com isso, dificuldades inerentes a cooperativas - como por exemplo conciliar propriedade coletiva, num meio social marcado pelo individualismo e pela propriedade privada, maior intensidade do trabalho e responsabilidade pela gestão, envolvimento no trabalho - assumem maior dimensão quando não resulta de um processo organizativo voluntário ou ideologicamente fundamentado.

Debates recentes sobre Economia Solidária e Terceiro Setor colocam a pequena produção e o trabalho associado em cooperativas como alternativas frente à redução do emprego e a crescente informalidade do trabalho, embora estes reconheçam seus limites, quando passam a trabalhar como subcontratadas para grandes empresas (Singer, 1998). Todavia, para que isso não ocorresse as cooperativas deveriam ser autônomas, sem uma vinculação direta com o grande capital, o que é um problema se pensarmos em sua sustentabilidade no mercado.

Numa situação de desemprego estrutural e de fracasso de experiências socialistas, recoloca-se o trabalho em cooperativas como possível saída, o 
que, aliás, vem sendo tentado historicamente desde o surgimento da grande indústria, e em situações de depressão econômica. A novidade, agora é a recuperação do trabalho associado como possibilidade de mercado e sua integração funcional com empresas e cadeias produtivas. Um caminho difícil, uma possibilidade de ocupação e acesso a renda, mas distante de qualquer autonomia.

\section{Referências Bibliográficas}

Abreu, Alice Rangel de Paiva (1986), O avesso da moda: trabalho a domicílio na indústria de confecção. São Paulo: HUCITEC.

Arbix, Glauco; Rodrigues-Pose, Andrés (1999), "Estratégias do desperdício: a guerra entre estados e municípios por novos investimentos e as incertezas do desenvolvimento", São Paulo, II International Workshop "Subnational Economic Governance” (mimeo).

Bonacich, Edna et al. (1994), Global Production. The Apparel Industry in the Pacific Rim. Philadelphia: Temple UP.

Dupas, Gilberto (1999), Economia global e exclusão social. São Paulo: Paz e Terra.

Gereffi, Gary (1997), "Competitividade e redes na cadeia produtiva do vestuário na América do Norte", Revista Latino-americana de Estudos do Trabalho, 3(6).

Neto, Leonardo Guimarães (1995), "Dinâmica recente das economias regionais brasileiras”, São Paulo em Perspectiva, 9(3).

Rios, Gilvando Sá Leitão (1979), Cooperativas agrícolas no nordeste brasileiro e mudança social. João Pessoa: Editora Universitária.

Santos, Milton (1999), "Guerra dos lugares", Folha de São Paulo, 8 de agosto, p. 3.

Sassen, Saskia (1998), As cidades na economia mundial. São Paulo: Studio Nobel.

Singer, Paul (1998), Globalização e desemprego: diagnósticos e alternativas. São Paulo: Contexto.

SUDENE (1997), Boletim Conjuntural Nordeste do Brasil. Recife, novembro. 